\title{
Elucidating the mechanisms of Tibetan medicine Ershiwuwei Lvxue Pill in the treatment of rheumatoid arthritis via a system pharmacological approach
}

Chuan Liu

Chengdu University of TCM: Chengdu University of Traditional Chinese Medicine

\section{Fangfang Fan}

Chengdu University of Traditional Chinese Medicine

\section{Lu Zhong}

Chengdu University of Traditional Chinese Medicine

\section{Ning Li}

Chengdu University of Traditional Chinese Medicine

\section{Yunsen Zhang}

Chengdu University of Traditional Chinese Medicine

Jinsong Su

Chengdu University of Traditional Chinese Medicine

\section{Qiqi Chu}

Chengdu University of Traditional Chinese Medicine

\section{Ce Tang}

Chengdu University of Traditional Chinese Medicine

Yi Zhang ( $\nabla$ zhangyi@cdutcm.edu.cn)

Chengdu University of TCM: Chengdu University of Traditional Chinese Medicine

Ya Tu

China Academy of Traditional Chinese Medicine: China Academy of Chinese Medical Sciences

\section{Research}

Keywords: Tibetan medicine, Ershiwuwei Ivxue pill, Rheumatoid arthritis, UPLC-Q-TOF/MS, Network pharmacology, Molecular docking simulation

Posted Date: October 16th, 2020

DOl: https://doi.org/10.21203/rs.3.rs-90771/v1

License: (c) (i) This work is licensed under a Creative Commons Attribution 4.0 International License. Read Full License 


\section{Abstract}

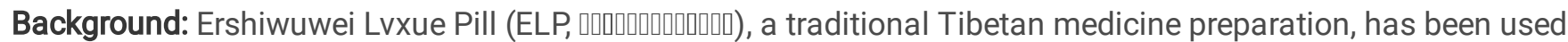
hundreds of years for the clinical treatment of rheumatoid arthritis (RA) in Tibet, China. Nevertheless, its chemical compositions and therapeutic mechanism are unclear.

Methods: In this work, a system pharmacological approach based on ultra-performance liquid chromatography/quadrupole time-of-flight mass spectrometry (UPLC-Q-TOF/MS), network pharmacology and molecular docking simulation was proposed for exploring the promising bioactive compounds and mechanisms for the treatment of RA.

Results: For the first time, the compounds database of ELP was successfully established and 96 compounds were identified based on UPLC-Q-TOF/MS analysis. Among them, 22 bioactive compounds were screened according to ADME, oral bioavailability and drug likeness. Screening based on relevant databases and topological analysis revealed that 22 bioactive ingredients participated in 46 potential target proteins and 12 signaling pathways in RA. The functional enrichment analysis indicated that ELP exerted the anti-RA effects via synergistically regulating multiple biological nodes of the disease network. In that, 10 targets with high degree value including IL6, TNF, TP53, AKT1, JUN, VEGFA, MAPK3, STAT3, IL1 $\beta$ and PTGS2. The pathways with greater $p$-value contribution are PI3K-Akt signaling pathway, Cytokine-cytokine receptor interaction, JAK-STAT signaling pathway, MAPK signaling pathway, TNF signaling pathway and Toll-like receptor signaling pathway. In addition, good molecular docking scores were highlighted between five promising bioactive compounds (ellagic acid, quercetin, kaempferol, galangin, coptisine) and five core targets (PTGS2, STAT3, VEGFA, MAPK3, TNF).

Conclusion: Overall, the present work revealed the material basis and potential mechanism of ELP treatment on RA and provides insight for further research. However, further studies are needed to validate the biological processes and effect pathways of ELP.

\section{Background}

Ershiwuwei Lvxue Pill (ELP), a traditional Tibetan patented prescription medicine, was officially recorded in the Drug Standard of the Ministry of Public Health of the Peoples Republic of China for the treatment of rheumatoid arthritis (RA) [1]. It was one of the commonly used drugs to cure gout and arthralgia, and demonstrated to effectively cure RA in clinical trials [2]. There are twenty-five kinds of medicine in ELP, including Asini sanguis pulvis, lignum rhamnellae, Dalbergiae odoriferae lignum, Santali albi lignum, Terminaliae belliricae fructus, Chebulae fructus, Travertine, Phyllanthi fructus, Myristicae semen, Caryophylli flos, Tsaoko fructus, Amomi fructus rotundus, Cassiae semen, Olibanum, Gossampini flos, Ambrette seed, Pterocephali herba, Gentianae radix et rhizome, Saxifrage, Vasaka, Fallopia aubertii, Fraxini cortex, Moschus, Croci stigma and Bovis calculus (Table S1). The complex chemical compositions of ELP mainly consists of phenolic acids, flavonoids and alkaloids, which have been reported to possess analgesic, anti-inflammatory and antimicrobial effects [3-6]. In addition, previous studies have shown that ELP treatment of RA may be associated with anti-inflammatory and immunosuppressive effects [7]. However, the current research on ELP contains two deficiencies: firstly, a clear relationship between ingredients and formula has not been scientifically established, largely due to its complex compound composition; secondly, in terms of the research on the drugs action mechanism, it is difficult to accurately reflect the multi-component, multi-target and multi-pathway characteristics of Tibetan medicine formula only by a single active ingredient or indicator component $[8,9]$. All those obstacles the efficacy evaluation and secondary development of Tibetan medicine ELP.

At present, a system pharmacological approach integrating ultra-performance liquid chromatography/quadrupole time-offlight mass spectrometry (UPLC-Q-TOF/MS), network pharmacology and molecular docking simulation have been widely used to study on the efficacious material basis and mechanism of traditional Chinese medicine or Tibetan medicine [10, 
11]. Given the technological merit of high sensitivity, selectivity, and speed of information collection, UPLC-Q-TOF/MS can effectively solve the problems such as complex components and difficult quantification in the modern analysis of natural medicine, and has outstanding advantages in the rapid discovery and characterization of target components $[12,13]$. Network pharmacology transforms a "one target, one drug" model into a "multicomponent, multitarget" model, which effectively illustrates the complex interaction between diseases and drugs from the network perspective and has been widely used in mechanism research in Tibetan medicine $[14,15]$. In addition, molecular docking simulation is a method of matching a ligand (drug) to a target molecule (receptor) by producing various components in different directions, as is an excellent tool in drug discovery [16-19]. Herein, the successful combinated molecular docking simulation and network pharmacology provides a powerful model for the treatment of RA with ELP.

In this work, 96 compounds in ELP were identified based on UPLC-Q-TOF/MS analysis. Then, combining network pharmacology and molecular docking simulation, the potential biological active compounds, targets and underlying mechanisms of ELP for treating RA were investigated.

\section{Material And Methods}

\section{Materials and chemicals}

ELP was obtained from Tibetan mandew Tibetan Medicine Co. Ltd (Tibet, China). The proportion of each composition in

ELP was showed in Table S1. HPLC grade acetonitrile and formic acid were supplied by Fisher Scientific (Fisher, Fair Lawn, NJ, USA). Chemical reference standards of gallic acid (110831-201906), chlorogenic acid (110753-201817), esculetin (110741-201708), ellagic acid (11959-201602), rutin (100080-201811), quercetin (100081-200907), and oleanolic acid (110709-201808) were purchased from National Institute for the Control of Pharmaceutical and Biological Products (Beijing, China). Corilagin (K-004-190509), orientin (H-044-181216), and isovitexin (Y-116-180803) were provided from Chengdu Ruifensi Biotechnology Co., Ltd. (Chengdu, China). Loganic acid (CHB190109), chebulinic acid (CHB190724), crocin I (CHB190308), ursodeoxycholic acid (CHB180626), (+)-Bicuculline (CHB190112), and $\beta$-boswellic acid (CHB190625) were purchased from Chengdu Chroma-Biotechnology Co., Ltd. (Chengdu, China). The purity of all the standards were above $98 \%$.

\section{Sample preparation}

Accurately-weighed ELP sample $(0.5 \mathrm{~g})$ was placed in a conical flask for ultrasound-assisted extraction with $70 \%$ methanol $(30 \mathrm{~mL})$ at $25{ }^{\circ} \mathrm{C}$ for $30 \mathrm{~min}$. The extracted solution was adjusted to the original weight by adding $70 \%$ methanol, and then, the extracted solution was centrifuged at $14000 \mathrm{rpm}$ for $5 \mathrm{~min}$. The supernatant was filtered through a $0.22 \mu \mathrm{m}$ microporous membrane filter prior to injection into the UPLC-Q-TOF/MS systems. Standard stock solutions of the reference standards were prepared by dissolving appropriate amounts of the pure substances in methanol.

\section{UPLC-Q-TOF/MS analysis}

Qualitative analysis of ELP was performed on Waters acquity UPLC (Waters, Milford, MA, USA). The chromatographic separation was performed on an Acquity UPLC BEH C18 column (2.1 mm $\times 100 \mathrm{~mm}, 1.7 \mu \mathrm{m}$, Waters), and the temperature was settled at $35^{\circ} \mathrm{C}$. The mobile phase was composed of acetonitrile $(A)$ and $0.1 \%$ aqueous formic acid solution (B), and the flow rate was $0.4 \mathrm{~mL} / \mathrm{min}$. The linear gradient program was performed as follows: 0-1 min, 5\% A; 1-3.5 min, 5-20\% A; 3.5-4.5 min, 20-25\% A; 4.5-6 min, 25-30\% A; 6-9 min, 30-50\% A; 9-11 min, 50-75\% A; 11-13 min, 75-90\% A;13-15 min, 90-95\% $A ; 15-16 \min , 95 \% A ; 16-16.5 \min , 95-5 \% A ; 16.5-19 \min , 5 \% A$.

Xevo G2-XS Q-TOF (Waters, Manchester, UK) equipped with electrospray ionization ion (ESI) source was applied for mass spectrometry data's acquisition in negative and positive ionization mode ranged from m/z 100 to m/z 1200. The 
parameters of the source were set as follows: the ion source temperature was set at $120{ }^{\circ} \mathrm{C}$, cone voltage $25 \mathrm{~V}$, capillary voltage $2.5 \mathrm{kV}$, collision energy $10 \mathrm{~V}$, desolvation temperature $350{ }^{\circ} \mathrm{C}$, and desolvation gas flow rate, $1000 \mathrm{~L} / \mathrm{h}$.

\section{Acquisition of active compounds and their targets}

All compounds obtained by UPLC-Q-TOF/MS analysis were retrieved on the basis of the absorption, distribution, metabolism, and excretion (ADME) parameters in the Traditional Chinese Medicine Systems Pharmacology Database and Analysis Platform (TCMSP, http://lsp.nwu.edu.cn/tcmsp.php), the following screening criteria were used: oral bioavailability $(\mathrm{OB}) \geq 30 \%$, drug-likeness $(\mathrm{DL}) \geq 0.18$ [20]. Then, the bioactive compounds selected by ADME were converted to a standard Canonical Simplified molecular input line entry specification (SMILES) format in PubChem database (https://pubchem.ncbi.nlm.nih.gov/), at the same time, SMILES format file was imported to Swiss Target Prediction database with properties for "Homo sapiens", and eventually ELP potential targets was built for the bioactive compounds information database [21].

\section{Acquisition of targets for RA}

Different genes related to RA were obtained from the Comparative Toxico genomics Database (CTD, http://ctdbase.org/) [22]; GeneCards HUMAN GENE DATABASE囚https://www.genecards.org/『[23]; and Online Mendelian Inheritance in Man (OMIM, http://www.omim.org/) [24]. The keyword "rheumatoid arthritis" was used to search for rheumatoid arthritis-related targets in CTD, GeneCards, and OMIM databases.

\section{Protein-Protein Interaction Data}

Protein-Protein Interaction (PPI) Data were extracted using STRING (https://string-db.org/) with a reasonable confidence range for PPI data scores [25]. Common targets of bioactive compounds associated with RA were inputted into the STRING database, with the species to "Homo sapiens," and the confidence scores higher than 0.7. The visualization of the PPI networks was conducted in Cytoscape 3.8 .0 software (http://www.cytoscape.org/) [26].

\section{Gene Ontology (GO) analysis and Kyoto Encyclopedia of Genes and Genomes (KEGG) Pathway analyses}

Based on potential common targets for this study, GO and KEGG analyses were conducted to predict the action mechanism of ELP in treating RA by using the Database for Annotation, Visualization, and Integrated Discovery (DAVID v6.8, https://david.ncifcrf.gov/) [27].

\section{Compound-Target-Pathway network}

Based on the results in DAVID database, the compound-target-pathway (C-T-P) network was created in Cytoscape 3.8.0 software. In a complex associative network, nodes and edges represent compounds/entities and their direct interactions, respectively. A high degree value equates to a prominent node status.

\section{Molecular docking simulation}

The molecular docking simulation was performed on the selected targets and corresponding compounds by using Maestro version 11.5 from the Schrodinger software suite. The lowest/minimum energy conformation was used for molecular docking via the default parameters. The docking score was the negative logarithm of the experimental dissociation/inhibition constant (pKd/pKi) and usually ranges from 0 to 10 (weak to strong combination force) [28]. The human protein structures with the highest resolution related to RA were selected at the UniProt database (https://www.uniprot.org/). Meanwhile, the X-ray crystal structures of these proteins were obtained at the RCSB PDB database (https://www.rcsb.org/). 


\section{Results}

\section{Identification of chemical compounds in ELP by UPLC-Q-TOF/MS}

A total of 96 compounds were identified based on UPLC-Q-TOF/MS in the positive and negative ion mode, and the total ion chromatogram was analyzed based on the chemical standard, fragmentation patterns, previous literature data and the

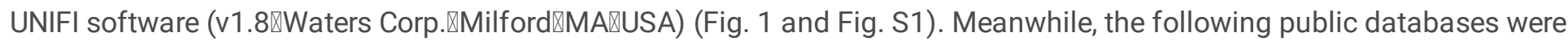
consulted: ChemSpider (http://www.chemspider.com), SciFinder Scholar (https://scifinder.cas.org). Finally, in the positive ion mode, 14 chromatographic peaks, mainly alkaloids, were characterized; and in the negative ion mode, 82 chromatographic peaks, mainly tannins, flavonoids, penylpropanoids, terpenoids, quinonoids, steroids, alkaloids, and other compounds (Table 1).

Fig. 1. UPLC-Q-TOF-MS total ion chromatogram of ELP. (A) negative mode; (B) positive mode.

Table 1. Characterization of the chemical constituents in ELP by UPLC-Q-TOF-MS.

\section{Tannins}

\section{Phenolic acid}

Peak 2 was characterized as quinic acid with $[\mathrm{M}-\mathrm{H}]^{-}$at $\mathrm{m} / \mathrm{z} 191.0561\left(\mathrm{C}_{7} \mathrm{H}_{12} \mathrm{O}_{6}\right)$. It displayed fragments at m/z $173[\mathrm{M}-\mathrm{H}-$ $\left.\mathrm{H}_{2} \mathrm{O}\right]^{-}, 127$ [M-H-2 $\left.\mathrm{H}_{2} \mathrm{O}-\mathrm{CO}\right]^{-}$[29]. Quinic acid is an important secondary metabolite formed by shikimic acid pathway [30]. Peak 3 with [M-H] $]^{-}$at $\mathrm{m} / \mathrm{z} 355.0310\left(\mathrm{C}_{14} \mathrm{H}_{12} \mathrm{O}_{11}\right)$ was identified as chebulic acid [31]. By comparison with the reference standard, peaks 5 and 38 with fragment ions $[\mathrm{M}-\mathrm{H}]^{-}$at $\mathrm{m} / \mathrm{z} 191.0561\left(\mathrm{C}_{7} \mathrm{H}_{6} \mathrm{O}_{5}\right)$ and $\mathrm{m} / \mathrm{z} 300.9973\left(\mathrm{C}_{14} \mathrm{H}_{6} \mathrm{O}_{8}\right)$, were characterized as gallic acid and ellagic acid, respectively [32]. Quinic acid was esterified mainly with caffeic acid, and five chlorogenic acid isomers were identified by combining the authentic standard and the fragment ion information. Peaks 12 , 17, and 25 had same ion [M-H] ' at m/z $353.0887\left(\mathrm{C}_{16} \mathrm{H}_{18} \mathrm{O}_{9}\right)$, and fragment ions at 191 [M-H-caffeoyl]; 179 [caffeic acid-H]', 173 [M-H-caffeoyl- $\left.\mathrm{H}_{2} \mathrm{O}\right]^{-}, 135$ [caffeic acid-H- $\left.\mathrm{CO}_{2}\right]^{-}$, which were identified as neochlorogenic acid (3-O-caffeoyl quinic acid), chlorogenic acid (5-0-caffeoyl quinic acid), and cryptochlorogenic acid (4-0-caffeoyl quinic acid), respectively [33]. Likewise, peaks 50 and 51 were isomers with $[\mathrm{M}-\mathrm{H}]^{-}$at $\mathrm{m} / \mathrm{z} 515.1195\left(\mathrm{C}_{25} \mathrm{H}_{24} \mathrm{O}_{12}\right)$, and fragment ions at $353[\mathrm{M}-\mathrm{H}-$ caffeoyl]', 191 [M-H-2caffeoyl]', 135 [caffeic acid-H-CO ${ }_{2}$ ], which were tentatively identified as isochlorogenic acid $\mathrm{A}$, isochlorogenic acid $\mathrm{B}$, respectively [34].

\section{Simple Gallic Acid Esters}

The basic structural units of tannin compounds are gallic acid and glucose, which contain or lose $-\mathrm{C}_{7} \mathrm{H}_{5} \mathrm{O}_{5}(\mathrm{~m} / \mathrm{z} 169)$, $\mathrm{C}_{7} \mathrm{H}_{4} \mathrm{O}_{4}\left(\mathrm{~m} / \mathrm{z}\right.$ 152), $-\mathrm{C}_{6} \mathrm{H}_{5} \mathrm{O}_{3}(\mathrm{~m} / \mathrm{z}$ 125) ion fragments in the MS/MS spectrum. Peak 4 had ion [M-H] at $\mathrm{m} / \mathrm{z} 331.0674$ $\left(\mathrm{C}_{13} \mathrm{H}_{16} \mathrm{O}_{10}\right)$, and fragment ions at m/z $313\left[\mathrm{M}-\mathrm{H}-\mathrm{H}_{2} \mathrm{O}\right]^{-}, 271\left[\mathrm{M}-\mathrm{H}-\mathrm{C}_{2} \mathrm{H}_{4} \mathrm{O}_{2}\right]^{-}, 211\left[\mathrm{M}-\mathrm{H}-\mathrm{C}_{4} \mathrm{H}_{8} \mathrm{O}_{4}\right]^{-}, 169$ [M-H-glc]', $124[\mathrm{M}-\mathrm{H}-\mathrm{glc}-$ $\left.\mathrm{CO}_{2}\right]^{]}$, thus peak 4 was tentatively characterized to be monogalloyl glucose [32] ( Fig. S2-1). Peaks 10, 14 and 15 had same ion [M-H] $]^{-}$at $\mathrm{m} / \mathrm{z} 483.0776\left(\mathrm{C}_{20} \mathrm{H}_{20} \mathrm{O}_{14}\right)$, were identified as digalloylglucose/ isomer [30]. In this way, peaks 22,26 , and 27 were characterized as trigalloylglucose/isomer [30], and the peaks 33 and 37 were characterized to be tetragalloylglucose/isomer, and peak 47 were identified to be 1,2,3,4,6-pentagalloylglucose [29, 31, 32, 35].

\section{Ellagitannins}

Ellagitannins, hydrolyzable tannin class of polyphenols, hydrolyzes with acids or bases to produce hexahydroxy diphenolic acid (HHDP), which were further spontaneously esterified into ellagic acid [36]. Peak 6 presented a precursor [M-H] ion at $\mathrm{m} / \mathrm{z} 781.0555\left(\mathrm{C}_{34} \mathrm{H}_{22} \mathrm{O}_{22}\right)$, and ions at m/z 601[M-H-glc]', 301 [HHDP], showing the existence of a gallic acid group, which 
was identified as punicalin [37]. Comparing the retention time and fragmentation patterns of reference standard, peaks 24 and 44 were assigned as corilagin and chebulinic acid, respectively [37,38]. Peaks 32 and 45 had identical ion [M-H] ${ }^{-}$at $\mathrm{m} / \mathrm{z}$ $953.0884\left(\mathrm{C}_{41} \mathrm{H}_{30} \mathrm{O}_{27}\right)$, and fragment ions at $\left.454[\mathrm{M}-\mathrm{H}-\mathrm{COOH}]^{2-}, 476[\mathrm{M}-2 \mathrm{H}]^{2-}, 301[\mathrm{HHDP}-\mathrm{H}]\right]^{-}$, were identified as chebulagic acid, and 3-galloyl-2,4-chebuloyl-1,6-HHDP-glucose, respectively [39,40].

\section{Flavonoids}

ESI-MS analysis of flavonoids exhibited some diagnostic features such as loss of methyl, methoxyl, $\mathrm{H}_{2} \mathrm{O}$ (18 Da), CO (28 $\mathrm{Da}), \mathrm{CO}_{2}$ (44 Da), $\mathrm{C}_{2} \mathrm{H}_{2} \mathrm{O}$ (42 Da) [41]. Meanwhile, for the identification of flavonoid aglycones, the retro-Diels-Alder (RDA) reaction provides structurally relevant information on the number and types of substituents in the A-and B-rings from the two $\mathrm{C}-\mathrm{C}$ bonds in Cleavage of the $\mathrm{C}$-ring [42]. In addition, flavonoids $\mathrm{C}$-glycosides in ESI-MS/MS spectra, ions of [M-H$\left.\mathrm{C}_{2} \mathrm{H}_{4} \mathrm{O}_{2}(60 \mathrm{Da})\right]^{-}$; [M-H- $\left.\mathrm{C}_{3} \mathrm{H}_{6} \mathrm{O}_{3}(90 \mathrm{Da})\right]^{3}$, [M- $\left.\mathrm{H}-\mathrm{C}_{4} \mathrm{H}_{8} \mathrm{O}_{4}(120 \mathrm{Da})\right]^{-}$are considered as characteristic of C-glycoside flavonoids under low collision energy. Unlike C-glycosides, O-glycosides generated the most intense aglycone ion after loss of sugar molecule under low collision energy. The presence of O-glucoside in flavonoids could be revealed by MS/MS experiment in product ion scan mode indicating neutral loss of a glucose moiety (162 Da), from precursor ions [43].

\section{Flavones}

Peaks 30 and 41 with [M-H] ion at $\mathrm{m} / \mathrm{z} 447.0933\left(\mathrm{C}_{21} \mathrm{H}_{20} \mathrm{O}_{11}\right)$ and $\mathrm{m} / \mathrm{z} 431.0988\left(\mathrm{C}_{21} \mathrm{H}_{20} \mathrm{O}_{10}\right)$, lost $\mathrm{C}_{3} \mathrm{H}_{6} \mathrm{O}_{3}$ and $\mathrm{C}_{4} \mathrm{H}_{8} \mathrm{O}_{4}$ in the $\mathrm{MS}^{2}$ spectrum, were confirmed as orientin and isovitexin by comparison with the authentic standard [44,45]. Likewise, peaks 18,20 and 46 could be tentatively identified as lutonarin, Isovitexin-7-0-glucoside, and vitexin 2"-0-rhamnoside, respectively [46-48]. Peak 65 showed a deprotonated ion [M-H] at $\mathrm{m} / \mathrm{z} 269.0831\left(\mathrm{C}_{15} \mathrm{H}_{10} \mathrm{O}_{5}\right)$ and was determined to be apigenin. It lost $\mathrm{CO}$ and $\mathrm{H}_{2} \mathrm{O}$, and formed base peaks at $\mathrm{m} / \mathrm{z} 251,241$ in the $\mathrm{MS}^{2}$ spectrum [13].

\section{Flavonols}

Peaks 35 and 40 gave identical ion [M-H] at m/z $609.1447\left(\mathrm{C}_{27} \mathrm{H}_{30} \mathrm{O}_{16}\right)$. By losing glucose (162 Da) and $\mathrm{H}_{2} \mathrm{O}$, peaks 35 showed ions [M-H] $^{-}$at $\mathrm{m} / \mathrm{z}$ 285, 267, which was assigned as kaempferol-3-O-gentiobioside [47]. Peaks 40 were identified as rutin by comparison with their authentic standard [49] (Fig. S2-2). Peak 66 displayed [M-H]' ion at m/z 301.0364 $\left(\mathrm{C}_{15} \mathrm{H}_{10} \mathrm{O}_{7}\right)$, and was accurately identified as quercetin by a reference standard and mass spectrometry [47]. Quercetin displayed fragment ions at $\mathrm{m} / \mathrm{z} 151\left[\mathrm{M}-\mathrm{H}-\mathrm{C}_{8} \mathrm{H}_{6} \mathrm{O}_{3}\right]^{-}, 121.0431\left[\mathrm{M}-\mathrm{H}-\mathrm{C}_{8} \mathrm{H}_{6} \mathrm{O}_{3}-\mathrm{CH}_{2} \mathrm{O}\right]^{-}$resulted from RDA cleavage [50]. Similarly, the other peaks $71,82,86$, and 87 could be preliminarily identified as kaempferol, kaempferide, galangin, and rhamnazin, respectively $[13,50]$.

\section{Isoflavones}

Peaks 31 and 72 were preliminarily characterized as cajanin and formononetin with $[\mathrm{M}-\mathrm{H}]^{-}$at $\mathrm{m} / \mathrm{z} 299.0568\left(\mathrm{C}_{16} \mathrm{H}_{12} \mathrm{O}_{6}\right)$ and $\mathrm{m} / \mathrm{z} 267.0657\left(\mathrm{C}_{16} \mathrm{H}_{12} \mathrm{O}_{4}\right)$, respectively. Peak 31 displayed fragments at m/z 284 [M-H-CH$]^{-}, 256\left[\mathrm{M}-\mathrm{H}-\mathrm{CH}_{3}-\mathrm{CO}\right]^{-}[51]$.

\section{Aurone}

Peak 34 with a deprotonated ion [M-H] at m/z $287.0559\left(\mathrm{C}_{15} \mathrm{H}_{12} \mathrm{O}_{6}\right)$ was determined to be maesopsin. By losting neutral molecules $\mathrm{H}_{2} \mathrm{O}$ and $\mathrm{CO}$, it formed base peaks at $\mathrm{m} / \mathrm{z} 251,241$ in the $\mathrm{MS}^{2}$ spectrum [52].

\section{Phenylpropenoids}

Peaks 13, 19, and 29 were characterized as esculin, esculetin, and fraxetin with deprotonated ions [M-H] ${ }^{-}$at $\mathrm{m} / \mathrm{z} 339.0716$ $\left(\mathrm{C}_{15} \mathrm{H}_{16} \mathrm{O}_{9}\right), \mathrm{m} / \mathrm{z} 177.0194\left(\mathrm{C}_{9} \mathrm{H}_{6} \mathrm{O}_{4}\right)$, and $\mathrm{m} / \mathrm{z} 207.0297\left(\mathrm{C}_{10} \mathrm{H}_{8} \mathrm{O}_{5}\right)$, respectively. Peak 19 displayed fragments at $\mathrm{m} / \mathrm{z} 149$ 
[M-H-CO]', 133[M-H-CO $]^{-}$, the same as the authentic standard [34,53,54].

\section{Terpenoids}

Monoterpenoids. Peak 16 with [M-H] ion at $\mathrm{m} / \mathrm{z} 375.1297\left(\mathrm{C}_{16} \mathrm{H}_{24} \mathrm{O}_{10}\right)$ lost a glucose moiety, $\mathrm{CO}_{2}$, and $\mathrm{H}_{2} \mathrm{O}$ in the $\mathrm{MS}^{2}$ spectrum, and it was confirmed as loganic acid by comparison with the authentic standard [12]. Peaks 23, 49, and 55 were preliminarily characterized as genipin-1-O-gentiobioside, sylvestroside $\mathrm{I}$, and cantleyoside with deprotonated ions [M- $\mathrm{H}]^{-}$at $\mathrm{m} / \mathrm{z} 549.1807\left(\mathrm{C}_{23} \mathrm{H}_{34} \mathrm{O}_{15}\right), \mathrm{m} / \mathrm{z} 747.2738\left(\mathrm{C}_{33} \mathrm{H}_{48} \mathrm{O}_{19}\right)$, and m/z $745.2544\left(\mathrm{C}_{33} \mathrm{H}_{46} \mathrm{O}_{19}\right)$, respectively [55,56].

\section{Diterpenoids}

Peaks 62 and 67 were tentatively characterized as diosbulbin J-glucoside and diosbulbin L-glucoside with deprotonated ions [M-H] $]^{-}$at $\mathrm{m} / \mathrm{z} 539.1772\left(\mathrm{C}_{26} \mathrm{H}_{36} \mathrm{O}_{12}\right)$ and $\mathrm{m} / \mathrm{z} 523.1837\left(\mathrm{C}_{25} \mathrm{H}_{32} \mathrm{O}_{12}\right)$, respectively. Peak 62 displayed fragments at $\mathrm{m} / \mathrm{z}$

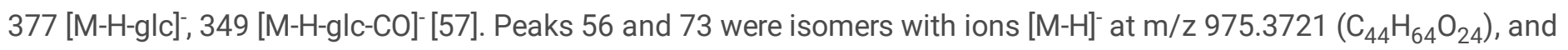
fragment ions at 813 [M-H-glc]', 651 [M-H-2glc]', respectively. Peak 56 was confirmed as crocin I by comparison with the authentic standard [38]. In the same manner, peaks 64 and 74 were tentatively identified as crocin II and cis-crocin II, respectively [58].

\section{Pentacyclic triterpenoids}

Peaks $76,77,78,84,85,88,89,90,91,92,94,95$, and 96 are preliminarily classified as triterpenoids from Olibanum. Among them, comparing the retention time and fragmentation patterns of reference standard, peaks 91,92 and 96 had same ion $[\mathrm{M}-\mathrm{H}]^{-}$at $\mathrm{m} / \mathrm{z} 455.3532\left(\mathrm{C}_{30} \mathrm{H}_{48} \mathrm{O}_{3}\right)$, and fragment ions along with $\mathrm{RDA}$ at $393\left[\mathrm{M}-\mathrm{H}-\mathrm{H}_{2} \mathrm{O}-\mathrm{CO}_{2}\right]^{-}, 239$ [B $\left.\mathrm{B}^{8,9}\right]^{-}, 217$ $\left[D^{8,9}\right]$; which were accurately identified as oleanolic acid, a-boswellic acid and $\beta$-boswellic acid (Fig. S2-3), respectively [12, 59]. Peaks 76 and 77 were isomers with ion $[\mathrm{M}-\mathrm{H}]^{-}$at $\mathrm{m} / \mathrm{z} 503.3388\left(\mathrm{C}_{30} \mathrm{H}_{48} \mathrm{O}_{6}\right)$, and were tentatively identified as trihydroxy-a-boswellic acid, trihydroxy- $\beta$-Boswellic acid, respectively [60]. Peak 78 presented a deprotonated ion [M-H] ${ }^{-}$at $\mathrm{m} / \mathrm{z} 501.3236\left(\mathrm{C}_{30} \mathrm{H}_{46} \mathrm{O}_{6}\right)$ and was preliminarily determined to be dihydroxy-11-Keto- $\beta$-boswellic acid [60]. Peaks 84 and 85 were isomers with ion [M-H] $]^{-}$at $\mathrm{m} / \mathrm{z} 471.3478\left(\mathrm{C}_{30} \mathrm{H}_{48} \mathrm{O}_{4}\right)$, and were tentatively identified as dihydroxy-a-boswellic acid, dihydroxy-a-boswellic acid, respectively, which had fewer hydroxyl group than compounds 76 and 77 [60]. Peaks 88, 89, and 90 were isomers with ion [M-H] $]^{-}$at $\mathrm{m} / \mathrm{z} 471.3478\left(\mathrm{C}_{30} \mathrm{H}_{48} \mathrm{O}_{4}\right)$, and were tentatively identified as 11-hydroxy-a-boswellic acid, 11-hydroxy- $\beta$-boswellic acid, and 2a-hydroxy-oleanolic acid, respectively [12]. Peak 88 displayed fragments at $\mathrm{m} / \mathrm{z}$ $409\left[\mathrm{M}-\mathrm{H}-\mathrm{H}_{2} \mathrm{O}-\mathrm{CO}_{2}\right]^{-}, 239\left[\mathrm{~B}^{8,9}\right]^{-}, 233\left[\mathrm{D}^{8,9}\right]$ ]. Peaks 94 and 95 were preliminarily determined to be Acetyl-11-keto- $\beta$-boswellic acid and 3-Acetyl- $\beta$-boswellic acid, respectively [12, 59-62].

\section{Quinonoids}

\section{Anthraquinones}

The main cleavage method of anthraquinones is to lose CO step by step and retain $p-\pi$ conjugated system in the parent nucleus group when induced by selective ion collision by mass spectrometry. In addition, side chain substituents are easily lost in the form of small neutral molecules such as $\mathrm{H}_{2} \mathrm{O}, \mathrm{CH}_{3}, \mathrm{CH}_{2}$ and $\mathrm{CO}_{2}$ [63]. Peaks 59, 68, and 75 were characterized as aurantio-obtusin-6-O- $\beta$-D-glucoside, obtusin, and aurantio-obtusin with deprotonated ions [M-H] ${ }^{-}$at $\mathrm{m} / \mathrm{z} 491.1199$ $\left(\mathrm{C}_{23} \mathrm{H}_{24} \mathrm{O}_{12}\right), \mathrm{m} / \mathrm{z} 343.0824\left(\mathrm{C}_{18} \mathrm{H}_{16} \mathrm{O}_{7}\right)$, and $\mathrm{m} / \mathrm{z} 329.0667\left(\mathrm{C}_{17} \mathrm{H}_{14} \mathrm{O}_{7}\right)$, respectively [64,65]. Peak 59 displayed fragments at $\mathrm{m} / \mathrm{z} 476\left[\mathrm{M}-\mathrm{H}-\mathrm{CH}_{3}\right]^{-}, 461\left[\mathrm{M}-\mathrm{H}-2 \mathrm{CH}_{3}\right]^{-}, 329$ [M-H-glc]', $286\left[\mathrm{M}-\mathrm{H}-\mathrm{glc}-\mathrm{CH}_{3}-\mathrm{CO}\right]^{-}$.

\section{Steroids}


Peak 83 with [M-H] 'ion at $\mathrm{m} / \mathrm{z} 3391.2856\left(\mathrm{C}_{24} \mathrm{H}_{40} \mathrm{O}_{4}\right)$ lost $\mathrm{H}_{2} \mathrm{O}$ and $\mathrm{COOH}$ in the $\mathrm{MS}^{2}$ spectrum, and it was confirmed as ursodeoxycholic acid (UDCA) by comparison with the authentic standard [66]. Likewise, peaks 80 and 81 were tentatively characterized as taurochenodeoxycholic acid (TDCA) and cholic acid (CA), respectively [10].

\section{Alkaloids}

Alkaloids are a kind of basic organic compounds containing nitrogen, which have good response in ESI (+) mode and mainly appear in the positive mode as $[\mathrm{M}+\mathrm{H}]^{+}$. In all, 14 alkaloids were identified. Peak 21 presented a deprotonated ion $[\mathrm{M}+\mathrm{H}]^{+}$at $\mathrm{m} / \mathrm{z} 314.1368\left(\mathrm{C}_{18} \mathrm{H}_{19} \mathrm{NO}_{4}\right)$ and fragment ions at $\mathrm{m} / \mathrm{z} 299\left[\mathrm{M}+\mathrm{H}-\mathrm{CH}_{3}\right]^{+}, 177\left[\mathrm{M}+\mathrm{H}-\mathrm{CH}_{3}-\mathrm{C}_{8} \mathrm{H}_{9} \mathrm{O}\right]^{+}, 121.0646$ $\left[\mathrm{C}_{8} \mathrm{H}_{9} \mathrm{O}\right]^{+}$, which was tentatively identified as $\mathrm{N}$-trans feruloyltyramine [67]. Peak 7 exhibited a quasi-molecular ion $[\mathrm{M}+\mathrm{H}]^{+}$at $\mathrm{m} / \mathrm{z} 192.0992\left(\mathrm{C}_{11} \mathrm{H}_{13} \mathrm{NO}_{2}\right)$. Meanwhile fragment ions at $\mathrm{m} / \mathrm{z} 177\left[\mathrm{M}+\mathrm{H}-\mathrm{CH}_{3}\right]^{+}, 149\left[\mathrm{M}+\mathrm{H}-\mathrm{CH}_{3}-\mathrm{CO}\right]^{+}$were also observed, which were consistent with the fragmental data of $\mathrm{N}$-methyl-2,3-dioxole-tetrahydroisoquinoline reported by literature [68]. Peak 28 presented a ion $[\mathrm{M}+\mathrm{H}]^{+}$at $\mathrm{m} / \mathrm{z} 342.1706\left(\mathrm{C}_{20} \mathrm{H}_{23} \mathrm{NO}_{4}\right)$ and fragment ions at m/z $311\left[\mathrm{M}+\mathrm{H}-\mathrm{CH}_{3} \mathrm{NH}_{2}\right]^{+}, 297[\mathrm{M}+\mathrm{H}-$ $\left.\left(\mathrm{CH}_{3}\right)_{2} \mathrm{NH}_{2}\right]^{+}, 279\left[\mathrm{M}+\mathrm{H}-\mathrm{CH}_{3} \mathrm{NH}_{2}-\mathrm{CH}_{3} \mathrm{OH}\right]^{+}$, which was tentatively identified as isocorydine [69]. Peaks 39 and 42 were tentatively characterized as scoulerine and tetrahydropalmatine with quasi-molecular ions $[\mathrm{M}+\mathrm{H}]^{+}$at $\mathrm{m} / \mathrm{z} 328.1553$ $\left(\mathrm{C}_{19} \mathrm{H}_{21} \mathrm{NO}_{4}\right)$ and $\mathrm{m} / \mathrm{z} 356.1857\left(\mathrm{C}_{21} \mathrm{H}_{25} \mathrm{NO}_{4}\right)$, respectively [70]. Peak 42 firstly loses the side chain $\mathrm{CH}_{3}$ to generate fragment ion at $\mathrm{m} / \mathrm{z} 341\left[\mathrm{M}+\mathrm{H}-\mathrm{CH}_{3}\right]^{+}$, and RDA fragments at $\mathrm{m} / \mathrm{z} 192\left[\mathrm{M}+\mathrm{H}-\mathrm{C}_{10} \mathrm{H}_{12} \mathrm{O}_{2}\right]^{+}, 165\left[\mathrm{M}+\mathrm{H}-\mathrm{C}_{11} \mathrm{H}_{13} \mathrm{NO}_{2}\right]^{+}[71]$. Based on the RDA reaction of the $\mathrm{C}$-ring and typical RDA-cleavage characteristics, peak 54 with ion $[\mathrm{M}+\mathrm{H}]^{+}$at $\mathrm{m} / \mathrm{z} 354.1339$ $\left(\mathrm{C}_{20} \mathrm{H}_{19} \mathrm{NO}_{5}\right)$ was identified as protopine [71]. Similarly, peaks 61, 63, and 70 were tentatively characterized as coptisine, jatrorrhizine and dehydrocorydaline [71,72]. Peak 43 was tentatively characterized as (-)-Corlumine [73,74]. Peak 48 was confirmed as (+)-Bicuculline by comparison with the authentic standard (Fig. S2-4), and peak 52 was characterized as (-)Bicuculline from previous literature $[73,75]$. Peaks 60 and 69 were characterized as (-)-chelidonine and dihydrochelerythrine with ions $[\mathrm{M}+\mathrm{H}]^{+}$at $\mathrm{m} / \mathrm{z} 354.1339\left(\mathrm{C}_{20} \mathrm{H}_{19} \mathrm{NO}_{5}\right)$ and $\mathrm{m} / \mathrm{z} 350.1361\left(\mathrm{C}_{21} \mathrm{H}_{19} \mathrm{NO}_{4}\right)$, respectively [68].

\section{Other compounds}

Peaks 1 and 9 were characterized as L-arginine and phenylalanine with $[\mathrm{M}-\mathrm{H}]^{-}$at $\mathrm{m} / \mathrm{z} 173.1041\left(\mathrm{C}_{6} \mathrm{H}_{14} \mathrm{~N}_{4} \mathrm{O}_{2}\right)$ and $\mathrm{m} / \mathrm{z}$ $164.0721\left(\mathrm{C}_{9} \mathrm{H}_{11} \mathrm{NO}_{2}\right)$, respectively $[76,77]$. Peaks 11 and 36 were characterized as glucosyringic acid and syringic acids [33]. Peak 57 presented a deprotonated ion [M-H] ${ }^{-}$at $\mathrm{m} / \mathrm{z} 269.0831\left(\mathrm{C}_{16} \mathrm{H}_{14} \mathrm{O}_{4}\right)$ and was preliminarily determined to be medicarpin [78]. Peaks 53 and 58 were characterized as cassiaside B2 and cassiaside with [M-H] ${ }^{-}$at $\mathrm{m} / \mathrm{z} 919.2737$ $\left(\mathrm{C}_{39} \mathrm{H}_{52} \mathrm{O}_{25}\right)$ and $\mathrm{m} / \mathrm{z} 403.1398\left(\mathrm{C}_{20} \mathrm{H}_{20} \mathrm{O}_{10}\right)$, respectively [64]. Peak 93 with a deprotonated ion [M-H] ${ }^{-}$at $\mathrm{m} / \mathrm{z} 227.2017$ $\left(\mathrm{C}_{14} \mathrm{H}_{28} \mathrm{O}_{2}\right)$ was determined to be myristic acid.

\section{Network pharmacology analysis}

\section{Potential bioactive compounds and targets of ELP in the treatment of RA}

After ADME screening, 22 potential bioactive compounds ( $O B \geq 30 \%, D L \geq 0.18$ ) in ELP were identified (Table 2). Firstly, 145 potential targets of the 22 bioactive compounds were obtained from the Swiss Target Prediction platform (Fig. 2 and Fig. 3) (Table S2). Secondly, 361 RA-related targets were retrieved from GeneCards, CTD, and OMIM databases. Finally, 46 targets associated with RA were obtained by precisely matching the two steps.

Table 2. Potential bioactive compounds ADME values of ELP.

Fig. 2 Structures of 22 potential bioactive compounds of ELP. 
Fig. 3 Compound-target network of ELP. In the network, there are 167 nodes and 292 edges. 22 bioactive compounds have interactions with 145 protein targets. The red circles represent the bioactive compounds, and the blue squares represent the targets.

\section{Protein-Protein Interaction (PPI) network}

The PPI relationship of 46 target genes was obtained by using STRING tool, and the visualization was realized by Cytoscape 3.8.0 software. The network of PPI relationships contained 46 nodes and 563 edges when a combined score of $>0.4$ was used (Fig. 4 and Table S3). The 10 target genes with the highest connectivity degree were selected as the hub genes for RA. So, the hub genes, which might play a crucial role in RA progression, were IL6, TNF, TP53, AKT1, JUN, VEGFA, MAPK3, STAT3, IL1B and PTGS2.

Fig. 4. Protein-protein interaction (PPI) network of ELP for the treatment of rheumatoid arthritis. In the network, there are 46 nodes and 563 edges. Each node represents the relevant gene, the size and color of the node represent the value of the free degree. (the larger the node, the redder the color, the greater the free degree).

\section{GO function and KEGG pathway enrichment analysis}

GO function and KEGG pathway enrichment analysis of the 46 candidate targets were conducted by DAVID v6.8 to explore the molecular mechanism of ELP in treating RA. GO evaluation were illustrated using biological process (BP), cell component (CC), and molecular function (MF) terms (Fig. 5A, 5B and 5C). A total of 79 enrichment results in the related items of $\mathrm{BP}$, involving regulation of apoptosis, protein amino acid phosphorylation, defense response, and intracellular signaling cascade; 20 enrichment results are related to $\mathrm{CC}$, which includes membrane-enclosed lumen, organelle lumen, cytosol, and cell fraction; 39 enrichment processes are related to the MF which cover the nucleoside binding, ATP binding, protein kinase activity, cytokine activity, etc. Enrichment results of each $p$-value were calculated ( $p<0.01$ was considered as significant enrichment). Subsequently, a total of 29 signaling pathways were obtained $(p<0.05)$ and 12 major signaling pathways closely associated with RA were screened (Fig. 5D). Therefore, ELP probably produced the anti-RA effects by synergistically regulating many biological pathways, such as PI3K-Akt signaling pathway, Cytokine-cytokine receptor interaction, JAK-STAT signaling pathway, MAPK signaling pathway, TNF signaling pathway, and Toll-like receptor signaling pathway, etc.

Fig. 5. The results of Gene Ontology enrichment and KEGG pathway analysis by DAVID. A: biological process (BP), B: cell component (CC), C: molecular function (MF), D: KEGG pathway analysis. The $P$ value of each biological process was less than 0.01 .

\section{Network construction and analysis}

A compound-target-pathway network (C-T-P) of ELP for treating RA was constructed using Cytoscape 3.8.0 software (Fig. 6). The network showed that the relationships among 22 bioactive compounds, 46 protein targets and 12 signaling pathways. With the excavation of the C-T-P network, the mechanism of ELP in treating RA was preliminarily understood.

Fig. 6. Compound-target-pathway Network (C-T-P) of ELP for treating RA. In the network, there are 80 nodes and 274 edges. The interaction relationship was shown between 22 bioactive compounds, 46 protein targets, and 12 signaling pathways. The green triangles represent the bioactive compounds, red circles represent targets, and blue squares represent signaling pathways.

\section{Molecular docking simulation}

Molecular docking simulation was performed using Maestro11.5 (Schrodinger Suites) between the 22 potential bioactive compounds and the top 10 targets from PPI network. The 3D structures of the 10 selected targets were obtained from the 
PDB database (https://www.rcsb.org/), which is a single global archive that includes experimentally determined atomiclevel 3D structures of biological macromolecules (DNA, RNA, and proteins) [79]. The docking scores were depicted in Fig. 7A and Table S4. The hydrogen bonding and $\pi-\pi$ stacking were involved between the targets and the potential compounds. Finally, according to the heat map analysis, good molecular docking scores were highlighted between five promising bioactive compounds (ellagic acid, quercetin, kaempferol, galangin, coptisine) and five core targets (PTGS2, STAT3, VEGFA, MAPK3, TNF). The typical schematic representation of three-dimensional (3D) and 2D molecular docking patterns of target proteins and compounds are shown in Fig. 7B, including PTGS2 with coptisine, STAT3 with ellagic acid, MAPK3 with quercetin and VEGFA with kaempferol. For instance, the binding mode of coptisine in the active site of PTGS2 had been represented in its 3D and 2D mode. Coptisine showed a H-bond interaction and three $\pi-\pi$ stacking. Accurately, the oxygen of coptisine forms a hydrogen bond with ASN382, and three Pi-Pi bonds were formed by binding the six-membered ring to HIE388 and HIS207, respectively.

Fig. 7. Molecular docking results between 10 targets and 22 bioactive compounds from ELP. A: Heatmap for docking score. Docking score represents a negative logarithm of experimental dissociation/inhibition constant value (pKd/pKi). B: The typical Schematic representation of the molecular docking (Including 2D structure and 3D structure). Droplet shapes represent amino acid groups that interact with compounds in $3 \AA \AA$. Capital letters represent the abbreviation for amino acids. (Color Fig. can be accessed in the online version.)

\section{Discussion}

As a common systemic inflammatory autoimmune disease, with high disability and incidence, RA can severely impair physical function and quality of life [80]. Recently discoveries have improved understanding of the rheumatoid inflammation and their consequences [81]. RA is characterized by infiltration of the synovial membrane in joints with $T$ cells, B cells, and monocytes and the common symptoms are musculoskeletal pain, swelling, and stiffness in clinical practice [82]. The pathophysiology of RA involves chronic inflammation of the synovial membrane, which can destroy articular cartilage and juxta articular bone [83]. As reported that the innate immune response produces some cytokines, among that, IL-1, IL-6 and TNF-a played important parts in progress of RA [84]. In addition, the process of RA involves the activation of multiple inflammatory signaling pathways and interactions with inflammatory cytokines [85]. Nevertheless, given the uncertainty and complexity of its pathogenesis, there's no specific medicine that can effectively treat RA. Modern therapies such as nonsteroidal anti-inflammatory drugs or pain medications only improve symptoms, but do not prevent damage progression and irreversible disability [83]. The mainly therapeutic strategy is applicated disease-modifying antirheumatic drugs for patient with RA at present. For example, methotrexate, one of the therapeutic drugs, is the most effective and commonly used first-line drug [86]. Unsatisfactory, it has certain limitations and large side effects. Consequently, it is urgent to discover and develop safe and effective therapeutic from traditional medicine.

ELP, a traditional Tibetan patented prescription medicine, which was one of the commonly used drugs to cure RA in clinical trials [2]. Hence, for the first time, a system pharmacological approach based on UPLC-Q-TOF/MS, network pharmacology and molecular docking simulation was applied to the prediction of promising bioactive compounds and mechanisms of ELP treating RA. In this work, it was found that 22 potential active compounds of ELP probably perform anti-RA effects via synergistically regulating multiple biological processes, the important six such as PI3K-Akt signaling pathway, Cytokinecytokine receptor interaction, JAK-STAT signaling pathway, MAPK signaling pathway, TNF signaling pathway, and Toll-like receptor signaling pathway. Concurrently, good molecular docking scores were highlighted between five promising bioactive compounds (ellagic acid, quercetin, kaempferol, galangin, coptisine) and five core targets (PTGS2, STAT3, VEGFA, MAPK3, TNF).

Excessive proliferation of fibroblast-like synoviocytes (FLSs) is one of the critical features of RA, leading to cartilage and bone destruction [87]. Studies have suggested that the PI3K/Akt signaling pathway contributes to excessive cell proliferation, migration, and invasion in RA-FLSs $[88,89]$. Bone marrow MSCs (BMSCs), play a key role in the healing of

Page $10 / 37$ 
bone defects, has been applied for the treatment of RA via activation of the PI3K/AKT signaling pathway [90]. Consequently, according the result of network analysis, one of the ELP mechanism in anti-RA effects may be associated with regulating the PI3K/AKT signaling pathway. Cytokine-cytokine receptor interaction, play a vital role in both innate and adaptive inflammatory host defenses, and development and repair processes aimed at the restoration of homeostasis, which is involved in the pathogenesis of inflammatory and autoimmune diseases including RA [91]. Notably, there are implicated in plenty studies also suggesting cytokine-cytokine interaction involved in the pathogenesis of RA [92]. Also, large post-injury increases in RA associated markers, and differential upregulation of the cytokine-cytokine receptor interaction pathway that is closely associated with inflammation [93]. JAK-STAT signaling pathway is a key player in RA progression. [94]. In previous studies, the levels of serum cytokine TNF- $\alpha$ and IL-1 $\beta$ are increased in RA patients. Meanwhile, activation of the JAK2-STAT3 pathway is regulated by inflammatory cytokines stimulation during the progression of RA $[95,96]$. The MAPK family includes p38MAPK, extracellular signal-regulated kinase (ERK) and c-Jun N-terminal kinase (JNK), which were activated in the synovium of RA patients [97, 98]. Accumulating studies indicated that the MAPK signal transduction pathway can regulate the inflammatory cytokine and downstream cell transduction pathways, thereby affecting the inflammation and destruction of joints [99]. It was reported that CCR5 silencing suppresses inflammatory response, inhibits viability, and promotes apoptosis of synovial cells in RA rats by inhibiting MAPK pathway [100]. TNF-a is a major cytokine implicated in RA [101]. Recently article revealed that miR-17 overexpression inhibited TRAF2 expression and its association with cIAP2, thereby suppressing TNF-a signaling pathways and downstream inflammatory proteins in RA SFs [102]. Emerging evidence shows that the activation of Toll-like receptor signaling pathway can initiate the perpetual cycle of inflammation in the arterial wall and the joint synovium in patients with RA [103]. It is demonstrated that functional suppression of RGS1 inhibits the inflammatory response and angiogenesis by inactivating the TLR signaling pathway in rats with collagen induced arthritis (CIA) [104]. Above investigations improved that the efficacy of ELP against RA via those inflammation associated with pathway. However, it is necessary to verify them through further experimental research.

There are many literatures analysis found that the potential targets such as PTGS2, STAT3, VEGFA, MAPK3 and TNF in the above rheumatoid arthritis signaling pathway network, had been reported. A literature for understanding the development of inflammatory arthritis revealed that LL-37 and IL17A can significantly enhanced PTGS2 and TNF gene expression, then release its downstream proinflammatory cytokines, PGE2 and TNF, contributing to enhancement of pathogenesis mechanisms of inflammatory arthritis [105]. Meanwhile, PTGS2, IL1 $\beta$, IL6, TNFA and CCL20 have been shown that mediators transformed RA-FLS to be a major source of pro-inflammatory in the pathology of RA [106]. The STAT proteins are usually inactive cytoplasmic proteins. Excess continuous exposure of STAT proteins induced pro-inflammatory cytokines or growth factors causes the development of RA [107]. STAT3, one of the STAT family members, has been proposed as an early pathophysiological event in RA. It was demonstrated that three STAT3-regulated genes BCL-2, SOCS3 and PIM1 could induce pathological lesion in RA via altered T cell effector function [108]. VEGF is a multifunctional cytokine that expressed in macrophages and neutrophils, inducing leukocyte accumulation and collagen deposition [109]. There is an evidence indicated that VEGFA promotes the migration and proliferation of endothelial cells, as well as inducing vascular permeability and mediating inflammation. VEGFA is a key factor in the development of pannus in RA [110]. Therefore, VEGFA inhibitors could disrupt new vessels and inhibit the delivery of nutritional proteins to sites of inflammation in RA [111]. Mitogen-activated protein kinases (MAPKs) are closely correlated with inflammatory diseases. MAPK3, one of the MAPKs has the same function participated in MAPK signaling pathway in RA [112]. Genes in the TNF family have been associated with RA, and may be a potential therapeutic target [113]. A plenty of evidences illustrated that TNF perpetuate synovial inflammation via activates RA-FLS inducing in a constellation of genes [101]. All these provide strong evidences for the prediction of ELP treat RA via intervention these key targets, but it is necessary to further validate the claims using molecular biological methods.

Molecular docking analysis showed that five promising bioactive compounds, ellagic acid, quercetin, kaempferol, galangin and coptisine, that docking own stable. The above compounds mainly belong to polyphenols, flavonoids, and alkaloids,

Page $11 / 37$ 
and a large of investigation explicated that all these compounds are efficiency in RA [114-116]. Previous studies have shown that ellagic acid alleviated adjuvant induced arthritis model in mice by modulation of pro- and anti-inflammatory cytokines (IL-1 $\beta$, TNF-a, IL-17, IL-10, and IFN- $\gamma$ ) [117]. Quercetin could diminish myeloperoxidase activity, and ROS level to aid control of the autoimmune inflammation in patients with RA [118]. Kaempferol inhibits the migration and invasion of fibroblast-like synovial cells in rheumatoid arthritis by blocking activation of MAPK pathway [119]. Experiments showed that galangin improved human RA FLS by inhibition of the NF-KB/NLRP3 pathway activation [120]. Coptisine has been reported to possess anti-inflammatory activity, that significantly inhibited the IL-1 $\beta$-induced NF-kB activation in human RA chondrocytes [121]. All above evidences proved that the prediction of bioactive compounds in ELP ant-RA is reasonable and reliable.

\section{Conclusion}

In this study, it was the first time that an integrative strategy based on UPLC-Q-TOF/MS coupled with UNIFI informatics platform was applied for chemical profile analysis of ELP. A sum of 96 compounds were identified or tentatively characterized from $70 \%$ methanol extraction of ELP by comparing retention times, mass spectra to authentic standards, fragmentation behaviors and data previously reported, including, tannins, flavonoids, penylpropanoids, terpenoids, quinonoids, steroids, alkaloids, and other compounds. Furthermore, based on the traditional Tibetan clinical efficacy and identified compounds of ELP in the treatment of RA, a compound-target-pathway network was constructed by relying on the network pharmacology method. In addition, good molecular docking scores were highlighted between five promising bioactive compounds (ellagic acid, quercetin, kaempferol, galangin, coptisine) and five core targets (PTGS2, STAT3, VEGFA, MAPK3, TNF). These targets were further related with the key signaling pathways such as PI3K/Akt, JAK-STAT, MAPK, TNF, Cytokine-cytokine receptor interaction, and Toll-like receptor, which could explain the anti-RA effects of ELP.

In summary, a system pharmacological approach using UPLC-Q-TOF/MS and network pharmacology with molecular docking simulation was applied to the prediction of promising bioactive compounds in ELP and mechanisms for the treatment of RA, which provides a new idea for the research of other Tibetan medicine prescriptions. Nevertheless, the bioactive compounds, biological targets and signaling pathways predicted needed to be confirmed and validated using CIA rat model in the further studies.

\section{Abbreviations}

ELP: Ershiwuwei Lvxue Pill; RA: rheumatoid arthritis; UPLC-Q-TOF/MS: ultra-performance liquid chromatography/quadrupole time-of-flight mass spectrometry; ADME: absorption, distribution, metabolism, and excretion; TCMSP: Traditional Chinese Medicine Systems Pharmacology Database and Analysis Platform; OB: oral bioavailability; DL: drug-likeness; SMILES: Simplified molecular input line entry specification; PPI: Protein-Protein Interaction; GO: Gene Ontology analysis; KEGG: Kyoto Encyclopedia of Genes and Genomes; DAVID: Annotation, Visualization, and Integrated Discovery; C-T-P: compound-target-pathway network; BP: biological process; CC: cell component; MF: molecular function

\section{Declarations}

\section{Acknowledgments}

Thanks Yi Zhang and Ya Tu for their guidances on the experiments.

\section{Author Contributions}

$\mathrm{YZ}$ and $\mathrm{YT}$ conceived and designed the experiments; $\mathrm{CL}$ performed the experiments and wrote the manuscript; $\mathrm{CL}, \mathrm{F}-\mathrm{FF}$ and LZ processed the data; LZ, YSZ, JS, QC and CT performed the partial experiments; CL, FFF, NL, YT and YZ provided critical review and revised the manuscript. All authors read and approved the final manuscript. 


\section{Funding}

This study was supported by National Key R\&D Program of China (2017YFC1703904), National Natural Science Foundation of China (81973573 and 81903922), Project First-Class Disciplines Development of Chengdu University of Traditional Chinese Medicine (CZYJC1903), and Xinglin Scholar Research Premotion Project of Chengdu University of TCM (CXTD2018015 and CXTD2018020).

\section{Availability of data and materials}

The datasets used and/or analyzed during the current study are available from the corresponding author on reasonable request.

\section{Ethics approval and consent to participate}

Not applicable

\section{Consent for publication}

All authors consent to publication of this study in the journal Chinese Medicine.

\section{Competing interests}

The authors declare that they have no competing interests.

\section{Author details}

1 College of Ethnic Medicine, Chengdu University of Traditional Chinese Medicine, Chengdu 611137, China;

2 Ethnic Medicine Academic Heritage Innovation Research Center, Chengdu University of Traditional Chinese Medicine, Chengdu 611137, China;

3 Innovative Institute of Chinese Medicine and Pharmacy, Chengdu University of Traditional Chinese Medicine, Chengdu 611137, China》

4 Development Research Center of Traditional Chinese Medicine, China Academy of Traditional Chinese Medicine, Beijing 100700, China.

\section{References}

1. Ministry of Health of the People's Republic of China. Drug Standard of Ministry of Public Health of the Peoples Republic of China. People's medical Publishing House, Beijing, 1995.

2. Ma JC, Xiawu LX. Observation on the curative effect of Tibetan medicine twenty-five taste donkey blood pills in treating gout. World Latest Medicine Information. 2019;19(25):145.

3. Wu JS, Luo Y, Deng DH, Su SY, Li S, Xiang L, et al. Coptisine from Coptis chinensis exerts diverse beneficial properties: A concise review. J Cell Mol Med. 2019;23(12):7946-60.

4. Hostetler GL, Ralston RA, Schwartz SJ. Flavones: Food Sources, Bioavailability, Metabolism, and Bioactivity. Adv Nutr. 2017;8(3):423-35.

5. Haleagrahara N, Miranda-Hernandez S, Alim MA, Hayes L, Bird G, Ketheesan N. Therapeutic effect of quercetin in collagen-induced arthritis. Biomed Pharmacother. 2017;90:38-46.

6. Yoon CH, Chung SJ, Lee SW, Park YB, Lee SK, Park MC. Gallic acid, a natural polyphenolic acid, induces apoptosis and inhibits proinflammatory gene expressions in rheumatoid arthritis fibroblast-like synoviocytes. Joint Bone Spine. 
2013;80(3):274-9.

7. Hu HG, Tao L, Wu JY, Zhao HY, Xiao X, Li YZ, et al. Discussion of Treating Effects and Its Mechanism of Tibetan Medicine Twenty-five Flavor Lvxue Pills to Bi Syndrome (Rheumatoid Arthritis). Journal of Basic Chinese Medicine. 2016;22(8):1053-6.

8. Liu C, Fan FF, Li XH, Wang WX, Tu Y, Zhang Y. Elucidation of the mechanism of action of the anti-cholecystitis effect of the Tibetan medicine “Dida” using network pharmacology. Trop J Pharm Res. 2020;19(7):1449-57.

9. Li XH, Hou Y, Wang XB, Zhang Y, Meng XL, Hu Y, et al. To Elucidate the Inhibition of Excessive Autophagy of Rhodiola crenulata on Exhaustive Exercise-Induced Skeletal Muscle Injury by Combined Network Pharmacology and Molecular Docking. Biol Pharm Bull. 2020;43(2):296-305.

10. Guo JY, Wang DM, Wang MJ, Zhou J, Pan YN, Wang ZZ, et al. Systematically characterize the substance basis of Jinzhen oral liquid and their pharmacological mechanism using UPLC-Q-TOF/MS combined with network pharmacology analysis. J Food Drug Anal. 2019;27(3):793-804.

11. Banerjee S, Bhattacharjee P, Kar A, Mukherjee PK. LC-MS/MS analysis and network pharmacology of Trigonella foenum-graecum-A plant from Ayurveda against hyperlipidemia and hyperglycemia with combination synergy. Phytomedicine. 2019;60:152944.

12. Li H, Yao WF, Liu QN, Xu J, Bao BH, Shan MQ, et al. Application of UHPLC-ESI-Q-TOF-MS to Identify Multiple Constituents in Processed Products of the Herbal Medicine Ligustri Lucidi Fructus. Molecules. 2017;22(5):689.

13. Ismail BB, Pu YF, Fan LH, Dandago MA, Guo MM, Liu DD. Characterizing the phenolic constituents of baobab (Adansonia digitata) fruit shell by LC-MS/QTOF and their in vitro biological activities. Sci Total Environ. 2019;694:133387.

14. Hopkins LA. Network pharmacology: the next paradigm in drug discovery. Nat Chem Biol. 2008;4(11):682-90.

15. Nam HH, Kim JS, Lee J, Seo YH, Kim HS, Ryu SM, et al. Pharmacological Effects of Agastache rugosa against Gastritis Using a Network Pharmacology Approach. Biomolecules. 2020;10(9):E1298.

16. Li Q, Zhao CC, Zhang YS, Du H, Xu T, Xu XM, et al. ${ }^{1}$ H NMR-Based Metabolomics Coupled with Molecular Docking Reveal the Anti-Diabetic Effects and Potential Active Components of Berberis vernae on Type 2 Diabetic Rats. Front Pharmacol. 2020;11:932.

17. Saikia S, Bordoloi M. Molecular docking: challenges, advances and its use in drug discovery perspective. Curr Drug Targets. 2019;20(5):501-21.

18. Kaur T, Madgulkar A, Bhalekar M, Asgaonkar K. Molecular Docking in Formulation and Development. Curr Drug Discov Technol. 2019;16(1):30-9.

19. Zhang Q, Li RL, Peng W, Zhang MM, Liu J, Wei SJ, et al. Identification of the Active Constituents and Significant Pathways of Guizhi-Shaoyao-Zhimu Decoction for the Treatment of Diabetes Mellitus Based on Molecular Docking and Network Pharmacology. Comb Chem High Throughput Screen. 2019;22(9):584-98.

20. Ru JL, Li P, Wang JN, Zhou W, Li BH, Huang C, et al. TCMSP: a database of systems pharmacology for drug discovery from herbal medicines. J Cheminformatics. 2014;6:13.

21. Gfeller D, Grosdidier A, Wirth M, Daina A, Michielin O, Zoete V. Swiss Target Prediction: a web server for target prediction of bioactive small molecules. Nucleic Acids Res. 2014;42:W32-8.

22. Davis AP, Murphy CG, Saraceni-Richards CA, Rosenstein MC, Wiegers TC, Mattingly CJ. Comparative Toxicogenomics Database: a knowledgebase and discovery tool for chemical-gene-disease networks. Nucleic Acids Res. 2009;37:D786-92.

23. Stelzer G, Rosen N, Plaschkes I, Zimmerman S, Twik M, Fishilevich S, et al. The GeneCards Suite: From Gene Data Mining to Disease Genome Sequence Analyses. Curr Protoc Bioinformatics. 2016;54:1.30.1-33.

24. Amberger JS, Bocchini CA, Schiettecatte F, Scott AF, Hamosh A. OMIM.org: Online Mendelian Inheritance in Man $\left(\mathrm{OMIM}{ }^{\circledR}\right)$, an online catalog of human genes and genetic disorders. Nucleic Acids Res. 2015;43(Database

Page 14/37 
issue):D789-98.

25. Szklarczyk D, Gable AL, Lyon D, Junge A, Wyder S, Huerta-Cepas J, et al. STRING v11: protein-protein association networks with increased coverage, supporting functional discovery in genome-wide experimental datasets. Nucleic Acids Res. 2019;47(D1):D607-13.

26. Otasek D, Morris JH, Bouças J, Pico AR, Demchak B. Cytoscape Automation: empowering workflow-based network analysis. Genome Biol. 2019;20(1):185.

27. Rashid M. Human genome variations: databases and bioinformatics resources. Polymorphism. 2020;4:21-30.

28. Kontoyianni, M. Docking and Virtual Screening in Drug Discovery. Mol Biol Rep. 2017;1647:255-66.

29. Kumar S, Chandra P, Bajpai V, Singh A, Srivastava M, Mishra DK, et al. Rapid qualitative and quantitative analysis of bioactive compounds from Phyllanthus amarus using LC/MS/MS techniques. Ind Crop Prod. 2015;69:143-52.

30. Molina-Calle M, Priego-Capote F, Luque de Castro MD. Characterization of Stevia leaves by LC-QTOF MS/MS analysis of polar and non-polar extracts. Food Chem. 2017;219:329-38.

31. Yang B, Kortesniemi M, Liu P, Karonen M, Salminen JP. Analysis of hydrolyzable tannins and other phenolic compounds in emblic leafflower (Phyllanthus emblica L.) fruits by high performance liquid chromatographyelectrospray ionization mass spectrometry. J Agric Food Chem. 2012;60(35):8672-83.

32. Chen HF, Li ML, Zhang C, Du WD, Shao HH, Feng YL, et al. Isolation and Identification of the Anti-Oxidant Constituents from Loropetalum chinense (R. Brown) Oliv. Based on UHPLC-Q-TOF-MS/MS. Molecules. 2018;(7):1720.

33. Cádiz-Gurrea ML, Fernández-Arroyo S, Joven J, Segura-Carretero A. Comprehensive characterization by UHPLC-ESI-QTOF-MS from an Eryngium bourgatii extract and their antioxidant and anti-inflammatory activities. Food Res Int. 2013;50(1):197-204.

34. Wang ML, Liu Y, Guo B, Wei LJ, Teng H, Chen XQ, et al. A dilute-and-shoot multispectral integration approach towards nontargeted component profiling of traditional herbal Yin-zhi-huang using liquid chromatography-photodiode array-ion trap/time-of-flight characterization. J Chromatogr B. 2018;1087:118-32.

35. Abu-Reidah IM, Ali-Shtayeh MS, Jamous RM, Arraez-Roman D, Segura-Carretero A. HPLC-DAD-ESI-MS/MS screening of bioactive components from Rhus coriaria L. (Sumac) fruits. Food Chem. 2015;166:179-91.

36. Landete JM. Ellagitannins, ellagic acid and their derived metabolites: A review about source, metabolism, functions and health. Food Res Int. 2011;44(5):1150-60.

37. Abdulla R, Mansur S, Lai HZ, Ubul A, Sun GY, Huang GZ, et al. Qualitative Analysis of Polyphenols in Macroporous Resin Pretreated Pomegranate Husk Extract by HPLC-QTOF-MS. Phytochem Anal. 2017;28(5):465-73.

38. Ying XH, Liu MY, Liang QL, Jiang M, Wang YM, Huang FK, et al. Identification and analysis of absorbed components and their metabolites in rat plasma and tissues after oral administration of 'Ershiwuwei Shanhu' pill extracts by UPLCDAD/Q-TOF-MS. J Ethnopharmacol. 2013;150(1):324-38.

39. Gunawan-Puteri MDPT, Kawabata J. Novel a-glucosidase inhibitors from Macaranga tanarius leaves. Food Chem. 2010;123(2):384-9.

40. Nuengchamnong N, Ingkaninan K. An on-line LC-MS/DPPH approach towards the quality control of antioxidative ingredients in Sahastara. Songklanakarin J Sci Technol. 2019;39(1):123-9.

41. Tiberti LA, Yariwake JH, Ndjoko K, Hostettmann K. On-line LC/UV/MS analysis of flavonols in the three apple varieties most widely cultivated in Brazil. J Am Chem Soc. 2007;18(1):100-5.

42. Fougère L, Silva DD, Destandau E, Elfakir C. TLC-MALDI-TOF-MS-based identification of flavonoid compounds using an inorganic matrix. Phytochem Anal. 2019;30(2):218-25.

43. Wang Y, Johnson-Cicalese J, Singh AP, Vorsa N. Characterization and quantification of flavonoids and organic acids over fruit development in American cranberry (Vaccinium macrocarpon) cultivars using HPLC and APCI-MS/MS. Plant Sci. 2017;262:91-102.

Page $15 / 37$ 
44. Wu LZ, Zhang XP, Xu XD, Zheng QX, Yang JS, Ding WL. Characterization of aromatic glycosides in the extracts of Trollius species by ultra high-performance liquid chromatography coupled with electrospray ionization quadrupole time-of-flight tandem mass spectrometry. J Pharm Biomed Anal. 2013;75:55-63.

45. Islam MN, Downey F, Ng CKY. Comprehensive profiling of flavonoids in Scutellaria incana L. using LC-Q-TOF-MS. Acta Chromatogr. 2013;25(3):555-69.

46. Li S, Wan CX, He LL, Yan ZG, Wang KS, Yuan MN, et al. Rapid identification and quantitative analysis of chemical constituents of Gentiana veitchiorum by UHPLC-PDA-QTOF-MS. Rev bras farmacogn. 2017;27(2):188-94.

47. He YJ, Li ZK, Wang W, Sooranna SR, Shi YT, Chen Y, et al. Chemical Profiles and Simultaneous Quantification of Aurantii fructus by Use of HPLC-Q-TOF-MS Combined with GC-MS and HPLC Methods. Molecules. 2018;23(9):2189.

48. Shao SY, Ting Y, Wang J, Sun J, Guo XF. Characterization and identification of the major flavonoids in Phyllostachys edulis leaf extract by UPLC-QTOF-MS/MS. Acta Chromatogr. 2020;32(4):228-37.

49. Liu MH, Tong X, Wang JX, Zou W, Cao H, Su WW. Rapid separation and identification of multiple constituents in traditional Chinese medicine formula Shenqi Fuzheng Injection by ultra-fast liquid chromatography combined with quadrupole-time-of-flight mass spectrometry. J Pharm Biomed Anal. 2013;74:141-55.

50. Xu L, Liu Y, Wu HF Wu H, Liu XC, Zhou A. Rapid identification of chemical profile in Gandou decoction by UPLC-Q-TOF$M^{E}$ coupled with novel informatics UNIFI platform. J Pharm Anal. 2020;10(1):35-48.

51. Qi Y, Li SZ, Pi ZF, Song FR, Lin N, Liu S, et al. Chemical profiling of Wu-tou decoction by UPLC-Q-TOF-MS. Talanta. 2014;118:21-9.

52. Presser A, Pradhan R, Bahr B, Paper DH, Mayer KK, Kopp B. Sulfemodin 8-O- $\beta$-d-Glucoside a New Sulfated Anthraquinone Glycoside and Antioxidant Phenolic Compounds from Rheum emodi. J Nat Prod. 2003;66(8):1107-9.

53. Kostova I, lossifova T. Chemical components of Fraxinus species. Fitoterapia. 2007;78(2):85-106.

54. Su RN, Luo WZ, Wei RR, Ao·WLJ, Zhong GY. Rapid identification of constituents of Urtica hyperborea using UPLC-ESIQ-TOF-MS/MS method. China J Chin Mater Med. 2019;44(8):1607-14.

55. Zhao XS, Yang MH, Wu HF, Shu XY. Fragmentation Behavior for Iridoid Glucosides and Anthraquinones in Morinda officinalis by ESI-Q-TOF MS/MS in Negative Ion Mode. J Chin Mass Spectr Soc. 2018;39(3):342-50.

56. Tang C, Li HJ, Fan G, Kuang TT, Meng XL, Zou ZM, et al. Network pharmacology and UPLC-Q-TOF/MS studies on the anti-arthritic mechanism of Pterocephalus hookeri. Trop J Pharm Res. 2019;17(6):1095-110.

57. Xu LL, Guo FX, Chi SS, Wang ZJ, Jiang YY, Liu B, et al. Rapid Screening and Identification of Diterpenoids in Tinospora sinensis Based on High-Performance Liquid Chromatography Coupled with Linear lon Trap-Orbitrap Mass Spectrometry. Molecules. 2017;22(6):912.

58. Karkoula E, Angelis A, Koulakiotis NS, Gikas E, Halabalaki M, Tsarbopoulos A, et al. Rapid isolation and characterization of crocins picrocrocin and crocetin from saffron using centrifugal partition chromatography and LCMS. J Sep Sci. 2018;41(22):4105-14.

59. Mannino G, Occhipinti A, Maffei ME. Quantitative Determination of 3-0-Acetyl-11-Keto-betaBoswellic Acid (AKBA) and Other Boswellic Acids in Boswellia sacra Flueck (syn. B. carteri Birdw) and Boswellia serrata Roxb. Molecules. 2016;21(10):1329.

60. Katragunta K, Siva B, Kondepudi N, Vadaparthi PR, Rao NR, Tiwari AK, et al. Estimation of boswellic acids in herbal formulations containing Boswellia serrata extract and comprehensive characterization of secondary metabolites using

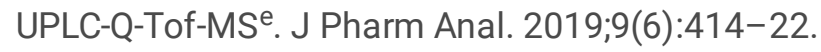

61. Roy NK, Parama D, Banik K, Bordoloi D, Devi AK, Thakur KK, et al. An Update on Pharmacological Potential of Boswellic Acids against Chronic Diseases. Int J Mol Sci. 2019;20(17):4101.

62. Gerbeth K, Husch J, Fricker G, Werz O, Schubert-Zsilavecz M, Abdel-Tawab M. In vitro metabolism permeation and brain availability of six major boswellic acids from Boswellia serrata gum resins. Fitoterapia. 2013;84:99-106. 
63. Zhao XS, Wei JH, Yang MH. Simultaneous Analysis of Iridoid Glycosides and Anthraquinones in Morinda officinalis Using UPLC-QqQ-MS/MS and UPLC-Q/TOF-MSE ${ }^{E}$. Molecules. 2018;23(5):1070.

64. Yan H, Zuo YM, Yuan E, Wang YF, Zhang ZL. Analysis of Chemical Constituents from Gardeniae Flos by UHPLC-Q-TOFMS. Journal of Chinese Medicinal Materials. 2018;41(6):1359-64.

65. Mbatchou VC, Tchouassi DP, Dickson RA, Annan K, Mensah AY, Amponsah IK, et al. Mosquito larvicidal activity of Cassia tora seed extract and its key anthraquinones aurantio-obtusin and obtusin. Parasites Vectors. 2017;10:562.

66. Tessier E, Neirinck L, Zhu Z. High-performance liquid chromatographic mass spectrometric method for the determination of ursodeoxycholic acid and its glycine and taurine conjugates in human plasma. J Chromatogr B. 2003;798(2):295-302.

67. Bajpai V, Singh A, Chandra P, Negi MPS, Kumar N, Kumar B. Analysis of phytochemical variations in dioecious Tinospora cordifolia stems using HPLC/QTOF MS/MS and UPLC/QqQLIT-MS/MS. Phytochem Anal. 2016;27(2):9299.

68. Qing ZX, Xu YQ, Yu LY, Liu JH, Huang XQ, Tang ZS, et al. Investigation of fragmentation behaviours of isoquinoline alkaloids by mass spectrometry combined with computational chemistry. Sci Rep. 2020;10(1):733.

69. Qing ZX, Cheng P, Zeng JG. Research progress on mass spectral fragmentation behaviour of alkaloids in Macleaya cordata. Chinese Traditional and Herbal Drugs. 2013;44(20):2929-39.

70. Xiao J, Song NN, Lu T, Pan YN, Song JY, Chen G, et al. Rapid characterization of TCM Qianjinteng by UPLC-QTOF-MS and its application in the evaluation of three species of Stephania. J Pharm Biomed Anal. 2018;156:284-96.

71. Yuan L, Yin J, Tian M, Xie JB, Wang Y, Hou ZG, et al. The classification and identification of complex chemical compositions in yanhusuo herb using UPLC-Q-TOF/MS. Anal Methods. 2016;8(10):2274-81.

72. Zhu JF, Yi XJ, Zhang JH, Chen SQ, Wu YJ. Chemical profiling and antioxidant evaluation of Yangxinshi Tablet by HPLC-ESI-Q-TOF-MS/MS combined with DPPH assay. J Pharm Biomed Anal. 2017;1060:262-71.

73. Chen QB, Aisa HA. Alkaloid constituents from Viola tianschanica. Phytochemistry. 2017;144:233-42.

74. Choe S, Lee E, Jin GN, Lee YH, Kim SY, Choi H, et al. Genetic and chemical components analysis of Papaver setigerum naturalized in Korea. Forensic Sci Int. 2012;222(1-3):387-93.

75. Shen Y, Han C, Jiang YX, Zhou XJ, Zhu ZN, Lei XX. Rapid quantification of four major bioactive alkaloids in Corydalis decumbens (Thunb.) Pers. by pressurised liquid extraction combined with liquid chromatography-triple quadrupole linear ion trap mass spectrometry. Talanta. 2011;84(4):1026-31.

76. Davids M, Swieringa E, Palm F, Smith DEC, Smulders YM, Scheffer PG, et al. Simultaneous determination of asymmetric and symmetric dimethylarginine L-monomethylarginine L-arginine and L-homoarginine in biological samples using stable isotope dilution liquid chromatography tandem mass spectrometry. J Chromatogr B. 2012;900:38-47.

77. Xu TF, Li SZ, Sun YF, Pi ZF, Liu S, Song FR, et al. Systematically characterize the absorbed effective substances of Wutou Decoction and their metabolic pathways in rat plasma using UHPLC-Q-TOF-MS combined with a target network pharmacological analysis. J Pharm Biomed Anal. 2017;141:95-107.

78. Gampe N, Darcsi A, Lohner S, Beni S, Kursinszki L. Characterization and identification of isoflavonoid glycosides in the root of Spiny restharrow (Ononis spinosa L.) by HPLC-QTOF-MS HPLC-MS/MS and NMR. J Pharm Biomed Anal. 2016;123:74-81.

79. Rose PW, Prlić A, Altunkaya A, Bi CX, Bradley AR, Christie CH, et al. The RCSB protein data bank: integrative view of protein gene and 3D structural information. Nucleic Acids Res. 2017;45(D1):D271-81.

80. Myasoedova E, Crowson CS, Kremers HM, Therneau TM, Gabriel SE. Is the incidence of rheumatoid arthritis rising? results from Olmsted County Minnesota 1955-2007. Arthritis Rheum. 2010;62(6):1576-82.

81. Aletaha D, Smolen JS. Diagnosis and Management of Rheumatoid Arthritis: A Review. Jama. 2018;320(13):1360-72. 
82. Smolen JS, Aletaha D, Mclnnes IB. Rheumatoid arthritis. Lancet. 2016;388(10055):2023-38.

83. Sparks JA. Rheumatoid Arthritis. Ann Intern Med. 2019;170(1):ITC1-16.

84. Fleischmann R. Interleukin-6 inhibition for rheumatoid arthritis. Lancet. 2017;389(10075):1168-70.

85. Noack M, Miossec P. Selected cytokine pathways in rheumatoid arthritis. Semin Immunopathol. 2017;39(4):365-83.

86. Burmester GR, Pope JE. Novel treatment strategies in rheumatoid arthritis. Lancet. 2017;389(10086):2338-48.

87. Liu Y, Pan YF, Xue YQ, Fang LK, Guo XH, Guo X, et al. uPAR promotes tumor-like biologic behaviors of fibroblast-like synoviocytes through PI3K/Akt signaling pathway in patients with rheumatoid arthritis. Cell Mol Immunol. 2018;15(2):171-81.

88. Liang YJ, Li H, Gong XB, Ding C. Long Non-coding RNA THRIL Mediates Cell Growth and Inflammatory Response of Fibroblast-Like Synoviocytes by Activating PI3K/AKT Signals in Rheumatoid Arthritis. Inflammation. 2020;43(3):1044-53.

89. Song B, Li XF, Yao Y, Xu QQ, Meng XM, Huang C, et al. BMP9 inhibits the proliferation and migration of fibroblast-like synoviocytes in rheumatoid arthritis via the PI3K/AKT signaling pathway. Int Immunopharmacol. 2019;74:105685.

90. Ye CY, Zhang W, Hang K, Chen M, Hou WD, Chen JZ, et al. Extracellular IL-37 promotes osteogenic differentiation of human bone marrow mesenchymal stem cells via activation of the PI3K/AKT signaling pathway. Cell Death Dis. 2019;10:753.

91. Aihaiti Y, Tuerhong X, Ye JT, Ren XY, Xu P. Identification of pivotal genes and pathways in the synovial tissue of patients with rheumatoid arthritis and osteoarthritis through integrated bioinformatic analysis. Mol Med Rep. 2020;22(4):3513-24.

92. An QY, Yan WK, Zhao Y, Yu KQ. Enhanced neutrophil autophagy and increased concentrations of IL-6 IL-8 IL-10 and MCP-1 in rheumatoid arthritis. Int Immunopharmacol. 2018;65:119-28.

93. King JD, Rowland G, Tezanos AGV, Warwick J, Kraus VB, Lattermann C, et al. Joint Fluid Proteome after Anterior Cruciate Ligament Rupture Reflects an Acute Posttraumatic Inflammatory and Chondrodegenerative State. Cartilage. 2020;11(3):329-37.

94. Villarino AV, Kanno Y, O'Shea JJ. Mechanisms and consequences of Jak-STAT signaling in the immune system. Nat Immunol. 2017;18(4):374-84.

95. Malemud CJ. The role of the JAK/STAT signal pathway in rheumatoid arthritis. Ther Adv Musculoskelet Dis. 2018;10(5-6):117-27.

96. McGarry T, Orr C, Wade S, Biniecka M, Wade S, Gallagher L, et al. JAK/STAT Blockade Alters Synovial Bioenergetics Mitochondrial Function and Proinflammatory Mediators in Rheumatoid Arthritis. Arthritis Rheumatol. 2018;70(12):1959-70.

97. Zhai KF, Duan H, Cui CY, Cao YY, Si JL, Yang HJ, et al. Liquiritin from Glycyrrhiza uralensis Attenuating Rheumatoid Arthritis via Reducing Inflammation Suppressing Angiogenesis and Inhibiting MAPK Signaling Pathway. J Agric Food Chem. 2019;67(10):2856-64.

98. Arab HH, Salama SA, Abdelghany TM, Omar HA, Arafa EA, Alrobaian MM, et al. Camel Milk Attenuates Rheumatoid Arthritis Via Inhibition of Mitogen Activated Protein Kinase Pathway. Cell Physiol Biochem. 2017;43(2):540-52.

99. Liu F, Feng XX, Zhu SL, Huang HY, Chen YD, Pan YF, et al. Sonic Hedgehog Signaling Pathway Mediates Proliferation and Migration of Fibroblast-Like Synoviocytes in Rheumatoid Arthritis via MAPK/ERK Signaling Pathway. Front Immunol. 2018;9:2847.

100. Lan YY, Wang YQ, Liu Y. CCR5 silencing reduces inflammatory response inhibits viability and promotes apoptosis of synovial cells in rat models of rheumatoid arthritis through the MAPK signaling pathway. J Cell Physiol. 2019;234(10):18748-62. 
101. Ni RR, Song GJ, Fu XH, Song RF, Li LL, Pu WD, et al. Reactive oxygen species-responsive dexamethasone-loaded nanoparticles for targeted treatment of rheumatoid arthritis via suppressing the iRhom2/TNF-a/BAFF signaling pathway. Biomaterials. 2020;232:119730.

102. Akhtar N, Singh AK, Ahmed S. MicroRNA-17 Suppresses TNF-a Signaling by Interfering with TRAF2 and clAP2 Association in Rheumatoid Arthritis Synovial Fibroblasts. J Immunol. 2016;197(6):2219-28.

103. Monaco C, Terrando N, Midwood KS. Toll-like receptor signaling: common pathways that drive cardiovascular disease and rheumatoid arthritis. Arthritis Care Res. 2011;63(4):500-11.

104. Hu XM, Tang JH, Zeng G, Hu XY, Bao P, Wu JL, et al. RGS1 silencing inhibits the inflammatory response and angiogenesis in rheumatoid arthritis rats through the inactivation of Toll-like receptor signaling pathway. J Cell Physiol. 2019;234(11):20432-42.

105. Kuensaen C, Chomdej S, Kongdang P, Sirikaew N, Jaitham R, Thonghoi S, et al. LL-37 alone and in combination with IL17A enhances proinflammatory cytokine expression in parallel with hyaluronan metabolism in human synovial sarcoma cell line SW982-A step toward understanding the development of inflammatory arthritis. PLoS One 2019;14(7):e0218736.

106. Lahoti TS, John K, Hughes JM, Kusnadi A, Murray IA, Krishnegowda G, et al. Aryl hydrocarbon receptor antagonism mitigates cytokine-mediated inflammatory signalling in primary human fibroblast-like synoviocytes. Ann Rheum Dis. 2013;72(10):1708-16.

107. O'Shea JJ, Plenge R. JAK and STAT signaling molecules in immunoregulation and immune-mediated disease. Immunity. 2012;36(4):542-50.

108. Anderson AE, Maney NJ, Nair N, Lendrem DW, Skelton AJ, Diboll J, et al. Expression of STAT3-regulated genes in circulating CD4+ T cells discriminates rheumatoid arthritis independently of clinical parameters in early arthritis. Rheumatology (Oxford). 2019;58(7):1250-8.

109. Lee YH, Bae SC. Correlation between circulating VEGF levels and disease activity in rheumatoid arthritis: a metaanalysis. Z Rheumatol. 2018;77(3):240-8.

110. Ramírez-Bello J, Cadena-Sandoval D, Fragoso JM, Barbosa-Cobos RE, Moreno-Eutímio MA, Saavedra-Salinas M, et al. The VEGFA -1154G/A polymorphism is associated with reduced risk of rheumatoid arthritis but not with systemic lupus erythematosus in Mexican women. J Gene Med. 2018;20(6):e3024.

111. Zhang Y, Qiu H, Zhang H, Wang L, Zhuang C, Liu R. Vascular endothelial growth factor A (VEGFA) polymorphisms in Chinese patients with rheumatoid arthritis. Scand J Rheumatol. 2013;42(5):344-8.

112. Ni S, Li CK, Xu NW, Liu X, Wang W, Chen WY, et al. Follistatin-like protein 1 induction of matrix metalloproteinase 1, 3 and 13 gene expression in rheumatoid arthritis synoviocytes requires MAPK JAK/STAT3 and NF-KB pathways. J Cell Physiol. 2018;234(1):454-63.

113. Loupasakis K, Kuo D, Sokhi UK, Sohn C, Syracuse B, Giannopoulou EG, et al. Tumor Necrosis Factor dynamically regulates the mRNA stabilome in rheumatoid arthritis fibroblast-like synoviocytes. PLoS One. 2017;12(7):e0179762.

114. Oliviero F, Scanu A, Zamudio-Cuevas Y, Punzi L, Spinella P. Anti-inflammatory effects of polyphenols in arthritis. J Sci Food Agric. 2018;98(5):1653-9.

115. Hughes SD, Ketheesan N, Haleagrahara N. The therapeutic potential of plant flavonoids on rheumatoid arthritis. Crit Rev Food Sci Nutr. 2017;57(17):3601-13.

116. Li SC, Liu X, Chen XR, Bi L. Research Progress on Anti-Inflammatory Effects and Mechanisms of Alkaloids from Chinese Medical Herbs. Evid-based Complement Altern Med. 2020;2020:1303524.

117. Allam G, Mahdi EA, Alzahrani AM, Abuelsaad AS. Ellagic acid alleviates adjuvant induced arthritis by modulation of pro- and anti-inflammatory cytokines. Central Eur J Immunol. 2016;41(4):339-49.

118. Haleagrahara N, Miranda-Hernandez S, Alim MA, Hayes L, Bird G, Ketheesan N. Therapeutic effect of quercetin in collagen-induced arthritis. Biomed Pharmacother. 2017;90:38-46.

Page 19/37 
119. Pan DM, Li N, Liu YY, Xu Q, Liu QP, You YT, et al. Kaempferol inhibits the migration and invasion of rheumatoid arthritis fibroblast-like synoviocytes by blocking activation of the MAPK pathway. Int Immunopharmacol. 2018;55:174-82.

120. Fu Q, Gao YZ, Zhao H, Wang ZJ, Wang J. Galangin protects human rheumatoid arthritis fibroblast-like synoviocytes via suppression of the NF-KB/NLRP3 pathway. Mol Med Rep. 2018;18(4):3619-24.

121. Zhou K, Hu L, Liao WJ, Yin DF, Rui F. Coptisine Prevented IL- $\beta$-Induced Expression of Inflammatory Mediators in Chondrocytes. Inflammation. 2016;39(4):1558-65.

\section{Tables}

Table 1. Characterization of the chemical constituents in ELP by UPLC-Q-TOF-MS. 


\begin{tabular}{|c|c|c|c|c|c|c|c|}
\hline NO. & $\begin{array}{l}\mathrm{Rt} \\
\text { (min) }\end{array}$ & Compound & $\begin{array}{l}\text { Molecular } \\
\text { formula }\end{array}$ & $\begin{array}{l}\text { Molecular } \\
\text { weight } \\
\text { (Da) }\end{array}$ & $\begin{array}{l}\text { Detected } \\
\text { ion }(\mathrm{m} / \mathrm{z}) \\
{[\mathrm{M}-} \\
\mathrm{H}]^{-} /[\mathrm{M}+\mathrm{H}]^{+}\end{array}$ & $\begin{array}{l}\text { Error } \\
(\mathrm{ppm})\end{array}$ & $\begin{array}{l}\mathrm{MS}^{2} \text { fragment ion } \\
(\mathrm{m} / \mathrm{z})\end{array}$ \\
\hline 1 & 0.53 & L-arginine & $\mathrm{C}_{6} \mathrm{H}_{14} \mathrm{~N}_{4} \mathrm{O}_{2}$ & 174.1117 & 173.1041 & -1.5 & - \\
\hline 2 & 0.61 & Quinic acid & $\mathrm{C}_{7} \mathrm{H}_{12} \mathrm{O}_{6}$ & 192.0634 & 191.0561 & -0.3 & $\begin{array}{l}\left.\text { 173.0456[M-H- } \mathrm{H}_{2} \mathrm{O}\right]^{-} \\
\text {127.907[M-H-2 } \\
\mathrm{CO}_{2} \mathrm{O}-\end{array}$ \\
\hline 3 & 0.78 & Chebulic acid & $\mathrm{C}_{14} \mathrm{H}_{12} \mathrm{O}_{11}$ & 356.038 & 355.031 & 0.8 & $\begin{array}{l}337.0201\left[\mathrm{M}-\mathrm{H}-\mathrm{H}_{2} \mathrm{O}\right]^{-} \\
293.0590\left[\mathrm{M}-\mathrm{H}-\mathrm{H}_{2} \mathrm{O}-\right. \\
\left.\mathrm{CO}_{2}\right]^{-}, 275.0197[\mathrm{M}-\mathrm{H}- \\
\left.2 \mathrm{H}_{2} \mathrm{O}-\mathrm{CO}_{2}\right]^{-}\end{array}$ \\
\hline 4 & 0.80 & Monogalloyl glucose & $\mathrm{C}_{13} \mathrm{H}_{16} \mathrm{O}_{10}$ & 332.0743 & 331.0674 & -0.9 & $\begin{array}{l}313.0020\left[\mathrm{M}-\mathrm{H}-\mathrm{H}_{2} \mathrm{O}\right]^{-}, \\
271.0459[\mathrm{M}-\mathrm{H}- \\
\left.\mathrm{C}_{2} \mathrm{H}_{4} \mathrm{O}_{2}\right]^{-}, 211.0951\left[^{\mathrm{M}-}\right. \\
\left.\mathrm{H}^{-} \mathrm{C}_{4} \mathrm{H}_{8} \mathrm{O}_{4}\right]^{-} \\
169.0142[\mathrm{M}-\mathrm{H}-\mathrm{glc}]^{-}, \\
124.9060[\mathrm{M}-\mathrm{H}-\mathrm{glc}- \\
\left.\mathrm{CO}_{2}\right]^{-}\end{array}$ \\
\hline 5 & 1.00 & Gallic acid* & $\mathrm{C}_{7} \mathrm{H}_{6} \mathrm{O}_{5}$ & 170.0215 & 169.0142 & 0.9 & $\begin{array}{l}125.0243\left[\mathrm{M}-\mathrm{H}-\mathrm{CO}_{2}\right]^{-} \\
107.0132\left[\mathrm{M}-\mathrm{H}-\mathrm{CO}_{2}^{-}\right. \\
\left.\mathrm{H}_{2} \mathrm{O}\right]^{-}\end{array}$ \\
\hline 6 & 1.28 & Punicalin & $\mathrm{C}_{34} \mathrm{H}_{22} \mathrm{O}_{22}$ & 782.0603 & 781.0515 & 2.9 & $\begin{array}{l}\text { 600.9894[M-H-glc]', } \\
300.8809[\mathrm{DPPH}]\end{array}$ \\
\hline 7 & 1.33 & $\begin{array}{l}\text { N-Methyl-2,3-dioxole- } \\
\text { Tetrahydroisoquinoline }\end{array}$ & $\mathrm{C}_{11} \mathrm{H}_{13} \mathrm{NO}_{2}$ & 191.0946 & 192.0992 & -3.3 & $\begin{array}{l}177.0765\left[\mathrm{M}+\mathrm{H}-\mathrm{CH}_{3}\right]^{+} \\
149.0807\left[\mathrm{M}+\mathrm{H}-\mathrm{CH}_{3}-\right. \\
\mathrm{CO}^{+}\end{array}$ \\
\hline 8 & 1.55 & 5-Galloylshikimic acid & $\mathrm{C}_{14} \mathrm{H}_{14} \mathrm{O}_{9}$ & 326.0638 & 325.0566 & 1.8 & $\begin{array}{l}\text { 169.0140[gallic acid- } \\
\mathrm{H}]^{-}, 153.0200, \\
125.0244 \text { [gallic acid-H- } \\
\left.\mathrm{CO}_{2}\right]^{-}\end{array}$ \\
\hline 9 & 1.63 & Phenylalanine & $\mathrm{C}_{9} \mathrm{H}_{11} \mathrm{NO}_{2}$ & 165.079 & 164.0721 & 0.9 & - \\
\hline 10 & 2.11 & $\begin{array}{l}\text { 1,2-di-O-galloyl-D- } \\
\text { glucose }\end{array}$ & $\mathrm{C}_{20} \mathrm{H}_{20} \mathrm{O}_{14}$ & 484.0853 & 483.0776 & -1.5 & $\begin{array}{l}\text { 331.0671[M-H-galloyl]', } \\
\text { 313.0562[M-H-galloyl-- } \\
\left.\mathrm{H}_{2} \mathrm{O}\right]^{-}, 271.0448, \\
211.0246, \\
169.0139 \text { [gallic acid- } \\
\mathrm{H}]^{-}\end{array}$ \\
\hline 11 & 2.13 & Glucosyringic Acid & $\mathrm{C}_{15} \mathrm{H}_{20} \mathrm{O}_{10}$ & 360.1057 & 359.0981 & 0.8 & $\begin{array}{l}\text { 197.0452[M-H-glc]', } \\
\text { 153.0535[M-H-glc- } \\
\left.\mathrm{CO}_{2}\right]^{-}\end{array}$ \\
\hline 12 & 2.23 & Neochlorogenic acid & $\mathrm{C}_{16} \mathrm{H}_{18} \mathrm{O}_{9}$ & 354.0951 & 353.0879 & 1.5 & $\begin{array}{l}\text { 191.0553[M-H- } \\
\text { caffeoyl]', }\end{array}$ \\
\hline
\end{tabular}

Page 21/37 
179.0349[caffeic acid$\mathrm{H}]$ ', 173.0480[M-Hcaffeoyl- $\left.\mathrm{H}_{2} \mathrm{O}\right]$;, 135.0492[caffeic acid$\left.\mathrm{H}-\mathrm{CO}_{2}\right]^{-}$

$\begin{array}{lllllll}13 & 2.52 & \text { Esculin } & \mathrm{C}_{15} \mathrm{H}_{16} \mathrm{O}_{9} & 340.0794 & 339.0716 & 0\end{array}$

177.0189[M-H-glc]', 149.0711[M-H-glc-CO]', 133.0295[M-H-glc$\left.\mathrm{CO}_{2}\right], 121.0625[\mathrm{M}-\mathrm{H}-$ glc-CO-CO]',

\begin{tabular}{|c|c|c|c|c|c|c|c|}
\hline 14 & 2.58 & $\begin{array}{l}\text { Digalloylglucose } \\
\text { isomer I / 2,3-di-O- } \\
\text { galloyl-D-glucose }\end{array}$ & $\mathrm{C}_{20} \mathrm{H}_{20} \mathrm{O}_{14}$ & 484.0853 & 483.0776 & -1.5 & $\begin{array}{l}331.0673,313.0565 \\
271.0456,211.0247, \\
169.0139\end{array}$ \\
\hline 15 & 2.65 & $\begin{array}{l}\text { Digalloylglucose } \\
\text { isomer II / 3,6-di-O- } \\
\text { galloyl-D-glucose }\end{array}$ & $\mathrm{C}_{20} \mathrm{H}_{20} \mathrm{O}_{14}$ & 484.0853 & 483.0779 & -1.5 & $\begin{array}{l}331.0671,313.0563 \\
271.0458,211.0245 \\
169.0139\end{array}$ \\
\hline 16 & 2.72 & Loganic acid* & $\mathrm{C}_{16} \mathrm{H}_{24} \mathrm{O}_{10}$ & 376.1369 & 375.1297 & -0.8 & $\begin{array}{l}\text { 213.0766[M-H-glc]', } \\
169.0864[\mathrm{M}-\mathrm{H}-\text { glc- } \\
\left.\mathrm{CO}_{2}\right]^{-}, 151.0761[\mathrm{M}-\mathrm{H}- \\
\left.\text { glc- }^{-} \mathrm{CO}_{2}-\mathrm{H}_{2} \mathrm{O}\right]^{-}\end{array}$ \\
\hline 17 & 2.89 & Chlorogenic acid* & $\mathrm{C}_{16} \mathrm{H}_{18} \mathrm{O}_{9}$ & 354.0951 & 353.0877 & 1.5 & $\begin{array}{l}\text { 191,0554[M-H- } \\
\text { caffeoyl] } \\
179.0347 \text { [Caffeic acid- } \\
\mathrm{H}^{-}\end{array}$ \\
\hline 18 & 3.11 & Lutonarin & $\mathrm{C}_{27} \mathrm{H}_{30} \mathrm{O}_{16}$ & 610.1534 & 609.1458 & 1.8 & $\begin{array}{l}\text { 447.0933[M-H-glc]; } \\
\text { 357.0616[M-H-glc-90]; } \\
\text { 327.0512[M-H-glc- } \\
\text { 120]; }\end{array}$ \\
\hline 19 & 3.12 & Esculetin* & $\mathrm{C}_{9} \mathrm{H}_{6} \mathrm{O}_{4}$ & 178.0266 & 177.0194 & -0.7 & $\begin{array}{l}\text { 149.0240[M-H-CO }]^{-} \\
\text {133.0288[M-H-CO }]^{-}, \\
121.0732[\mathrm{M}-\mathrm{H}-\mathrm{CO}-\mathrm{CO}]^{-}\end{array}$ \\
\hline 20 & 3.16 & $\begin{array}{l}\text { Isovitexin-7-0- } \\
\text { glucoside }\end{array}$ & $\mathrm{C}_{27} \mathrm{H}_{30} \mathrm{O}_{15}$ & 594.1584 & 593.1512 & 1.3 & $\begin{array}{l}\text { 503.1197[M-H-90]', } \\
\text { 473.1085[M-H-120]; } \\
\text { 341.0661[M-H-glc-90]', } \\
\text { 311.0551[M-H-glc- } \\
\text { 120]', }\end{array}$ \\
\hline 21 & 3.17 & $\begin{array}{l}\mathrm{N} \text {-trans } \\
\text { Feruloyltyramine }\end{array}$ & $\mathrm{C}_{18} \mathrm{H}_{19} \mathrm{NO}_{4}$ & 313.1314 & 314.1368 & -0.6 & $\begin{array}{l}299.1100\left[\mathrm{M}+\mathrm{H}-\mathrm{CH}_{3}\right]^{+} \\
\text {177.0520, } \\
121.0646\left[\mathrm{C}_{8} \mathrm{H}_{9} \mathrm{O}\right]^{+}\end{array}$ \\
\hline 22 & 3.19 & 1,2,6-Trigalloylglucose & $\mathrm{C}_{27} \mathrm{H}_{24} \mathrm{O}_{18}$ & 636.0963 & 635.0891 & -1.9 & $\begin{array}{l}\text { 483.0780[M-H-galloyl]', } \\
465.1779[\mathrm{M}-\mathrm{H}-\text { galloyl- } \\
\left.\mathrm{H}_{2} \mathrm{O}\right]^{-}, 331.1322[\mathrm{M}-\mathrm{H}- \\
\text { 2galloyl]; } 313.0762[\mathrm{M}- \\
\left.\mathrm{H}-2 \text { galloyl-H }{ }_{2} \mathrm{O}\right]^{-} \\
\text {178.9124[M-H- } \\
\text { 3galloyl]; }\end{array}$ \\
\hline
\end{tabular}




\begin{tabular}{|c|c|c|c|c|c|c|c|}
\hline 23 & 3.29 & $\begin{array}{l}\text { Genipin-1-0- } \\
\text { Gentiobioside }\end{array}$ & $\mathrm{C}_{23} \mathrm{H}_{34} \mathrm{O}_{15}$ & 550.1898 & 549.1807 & -1.2 & 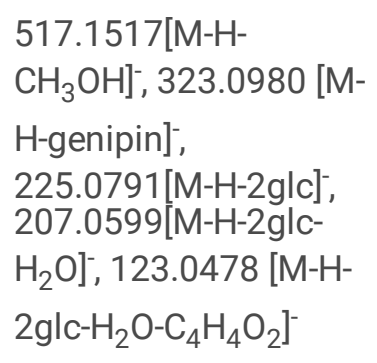 \\
\hline 24 & 3.37 & Corilagin* & $\mathrm{C}_{27} \mathrm{H}_{22} \mathrm{O}_{18}$ & 634.086 & 633.0733 & 2.2 & $\begin{array}{l}\text { 481.0671[M-H-galloyl]', } \\
\text { 463.0520[M-H-galloyl- } \\
\left.\mathrm{H}^{-} \mathrm{O}\right]^{-}, 300.9992[\mathrm{M}-\mathrm{H}- \\
\left.\text { galloyl- } \mathrm{H}_{2} \mathrm{O}-\mathrm{Hex}\right]^{-}\end{array}$ \\
\hline 25 & 3.40 & Cryptochlorogenic acid & $\mathrm{C}_{16} \mathrm{H}_{18} \mathrm{O}_{9}$ & 354.0951 & 353.0887 & 1.5 & 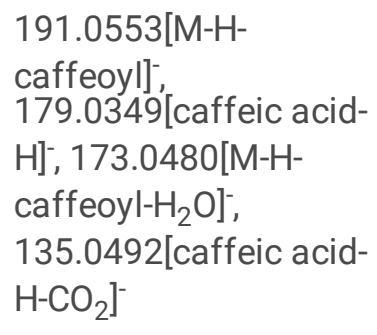 \\
\hline 26 & 3.49 & 1,2,6-Trigalloylglucose & $\mathrm{C}_{27} \mathrm{H}_{24} \mathrm{O}_{18}$ & 636.0963 & 635.0891 & -1.9 & $\begin{array}{l}\text { 483.0780[M-H-galloyl]', } \\
\text { 465.1779[M-H-galloyl- } \\
\left.\mathrm{H}_{2} \mathrm{O}\right]^{-}, 331.1322[\mathrm{M}-\mathrm{H}- \\
\text { 2galloyl]', 313.0762[M- } \\
\left.\mathrm{H}-2 \text { galloyl- } \mathrm{H}_{2} \mathrm{O}\right]^{-} \text {, } \\
\text { 178.9124[M-H- } \\
\text { 3galloyl]', }\end{array}$ \\
\hline 27 & 3.55 & 1,2,6-Trigalloylglucose & $\mathrm{C}_{27} \mathrm{H}_{24} \mathrm{O}_{18}$ & 636.0963 & 635.0891 & -1.9 & $\begin{array}{l}\text { 483.0780[M-H-galloyl]', } \\
465.1779[\mathrm{M}-\mathrm{H}-\text { galloyl- } \\
\left.\mathrm{H}_{2} \mathrm{O}\right]^{-}, 331.1322[\mathrm{M}-\mathrm{H}- \\
\text { 2galloyl]', 313.0762[M- } \\
\left.\mathrm{H}-2 \text { galloyl- } \mathrm{H}_{2} \mathrm{O}\right]^{-} \text {, } \\
\text { 178.9124[M-H- } \\
\text { 3galloyl]', }\end{array}$ \\
\hline 28 & 3.68 & Isocorydine & $\mathrm{C}_{20} \mathrm{H}_{23} \mathrm{NO}_{4}$ & 341.1627 & 342.1706 & 0.1 & $\begin{array}{l}311.1422[\mathrm{M}+\mathrm{H}- \\
\left.\mathrm{CH}_{3} \mathrm{NH}_{2}\right]^{+}, \\
297.1134[\mathrm{M}+\mathrm{H}- \\
\left.\left(\mathrm{CH}_{3}\right)_{2} \mathrm{NH}_{2}\right]^{+} \\
279.1079[\mathrm{M}+\mathrm{H}- \\
\left.\mathrm{CH}_{3} \mathrm{NH}_{2}-\mathrm{CH}_{3} \mathrm{OH}\right]^{+}\end{array}$ \\
\hline 29 & 3.69 & Fraxetin & $\mathrm{C}_{10} \mathrm{H}_{8} \mathrm{O}_{5}$ & 208.0372 & 207.0297 & -0.8 & $\begin{array}{l}\text { 192.0062[M-H-CH}]^{-} \\
\text {164.0111[M-H- } \mathrm{CH}_{3}^{-} \\
\mathrm{CO}]^{-}\end{array}$ \\
\hline 30 & 3.81 & Orientin* & $\mathrm{C}_{21} \mathrm{H}_{20} \mathrm{O}_{11}$ & 448.1006 & 447.0933 & 0.5 & $\begin{array}{l}\text { 357.0618[M-H-90]; } \\
\text { 327.0511[M-H-120]; }\end{array}$ \\
\hline 31 & 3.83 & Cajanin & $\mathrm{C}_{16} \mathrm{H}_{12} \mathrm{O}_{6}$ & 300.0634 & 299.0568 & 1.2 & $\begin{array}{l}284.0324\left[\mathrm{M}-\mathrm{H}-\mathrm{CH}_{3}\right]^{-} \\
(100 \%), 256.0[\mathrm{M}-\mathrm{H}- \\
\left.\mathrm{CH}_{3}-\mathrm{CO}\right]^{-}\end{array}$ \\
\hline
\end{tabular}




\begin{tabular}{|c|c|c|c|c|c|c|c|}
\hline 32 & 3.92 & Chebulagic acid & $\mathrm{C}_{41} \mathrm{H}_{30} \mathrm{O}_{27}$ & 954.0975 & 953.0884 & -0.2 & $\begin{array}{l}454.2341[\mathrm{M}-\mathrm{H}- \\
\mathrm{COOH}]^{2-}, 476.3053 \text { [M- } \\
2 \mathrm{H}]^{2-}, 300.9994[\mathrm{HHDP}- \\
\mathrm{H}]^{-}\end{array}$ \\
\hline 33 & 3.99 & $\begin{array}{l}1,2,3,6- \\
\text { Tetragalloylglucose }\end{array}$ & $\mathrm{C}_{34} \mathrm{H}_{28} \mathrm{O}_{22}$ & 788.1072 & 787.1003 & 0.9 & $\begin{array}{l}635.0890[\mathrm{M}-\mathrm{H}-\text { galloyl]', } \\
483.0776[\mathrm{M}-\mathrm{H}- \\
\text { 2galloyl]', 331.0931[M- } \\
\text { H-3galloyl]; }\end{array}$ \\
\hline 34 & 4.01 & Maesopsin & $\mathrm{C}_{15} \mathrm{H}_{12} \mathrm{O}_{6}$ & 288.0637 & 287.0559 & 1.1 & $\begin{array}{l}269.0461\left[\mathrm{M}-\mathrm{H}-\mathrm{H}_{2} \mathrm{O}\right]^{-} \\
259.0622[\mathrm{M}-\mathrm{H}-\mathrm{CO}]^{-} \\
215.0702[\mathrm{M}-\mathrm{H}-\mathrm{CO}- \\
\left.\mathrm{CO}_{2}\right]^{-}\end{array}$ \\
\hline 35 & 4.03 & $\begin{array}{l}\text { Kaempferol-3-0- } \\
\text { gentiobioside }\end{array}$ & $\mathrm{C}_{27} \mathrm{H}_{30} \mathrm{O}_{16}$ & 610.1534 & 609.1461 & 1.8 & $\begin{array}{l}\text { 285.0783[M-H-2glc];, } \\
267.0585[\mathrm{M}-\mathrm{H}-2 \mathrm{glc}- \\
\left.\mathrm{H}_{2} \mathrm{O}\right]-;\end{array}$ \\
\hline 36 & 4.05 & Syringic acid & $\mathrm{C}_{9} \mathrm{H}_{10} \mathrm{O}_{5}$ & 198.0528 & 197.0456 & 0.8 & $\begin{array}{c}182.0568\left[\mathrm{M}-\mathrm{H}-\mathrm{CH}_{3}\right]^{-} \\
179.0347\left[\mathrm{M}-\mathrm{H}-\mathrm{H}_{2} \mathrm{O}\right]^{-} \\
135.0033\left[\mathrm{M}-\mathrm{H}-\mathrm{CO}_{2}\right]^{-}\end{array}$ \\
\hline 37 & 4.09 & $\begin{array}{l}1,3,4,6- \\
\text { Tetragalloylglucose }\end{array}$ & $\mathrm{C}_{34} \mathrm{H}_{28} \mathrm{O}_{22}$ & 788.1072 & 787.1003 & 0.9 & $\begin{array}{l}635.0890[\mathrm{M}-\mathrm{H}-\text { galloyl]', } \\
483.0776[\mathrm{M}-\mathrm{H}- \\
\text { 2galloyl]', 331.0931[M- } \\
\text { H-3galloyl]-, }\end{array}$ \\
\hline 38 & 4.39 & Ellagic acid* & $\mathrm{C}_{14} \mathrm{H}_{6} \mathrm{O}_{8}$ & 302.0063 & 300.9973 & -1.1 & $\begin{array}{l}\left.\text { 283.9963[M-H- } \mathrm{H}_{2} \mathrm{O}\right]^{-}, \\
\text {273.0189[M-H-CO]', } \\
\text { 257.0082[M-H-CO2]', } \\
\text { 229.0141[M-H-CO } 2^{-} \\
\mathrm{CO}^{-}\end{array}$ \\
\hline 39 & 4.13 & Scoulerine & $\mathrm{C}_{19} \mathrm{H}_{21} \mathrm{NO}_{4}$ & 327.1471 & 328.1553 & 0.1 & $\begin{array}{l}296.1267[\mathrm{M}+\mathrm{H}- \\
\left.\mathrm{CH}_{3} \mathrm{OH}\right]^{+} \\
178.0829[\mathrm{M}+\mathrm{H}- \\
\left.\mathrm{C}_{9} \mathrm{H}_{10} \mathrm{O}_{2}\right]^{+} \\
163.0598[\mathrm{M}+\mathrm{H}- \\
\left.\mathrm{C}_{9} \mathrm{H}_{10} \mathrm{O}_{2}-\mathrm{CH}_{3}\right]^{+}\end{array}$ \\
\hline 40 & 4.16 & Rutin* & $\mathrm{C}_{27} \mathrm{H}_{30} \mathrm{O}_{16}$ & 610.1534 & 609.1447 & 1.8 & $\begin{array}{l}\text { 300.9992[M-H- } \\
\text { Rutinose]; } \\
151.0054\left[\mathrm{~A}^{1,3}\right]-\end{array}$ \\
\hline 41 & 4.23 & Isovitexin* & $\mathrm{C}_{21} \mathrm{H}_{20} \mathrm{O}_{10}$ & 432.1057 & 431.0988 & 0.6 & $\begin{array}{l}\text { 341.0671[M-H-90]' } \\
311.0563[\mathrm{M}-\mathrm{H}-120]^{-}\end{array}$ \\
\hline 42 & 4.25 & Tetrahydropalmatine & $\mathrm{C}_{21} \mathrm{H}_{25} \mathrm{NO}_{4}$ & 355.1783 & 356.1857 & -0.6 & $\begin{array}{l}341.1520\left[\mathrm{M}+\mathrm{H}-\mathrm{CH}_{3}\right]^{+} \\
192.0992[\mathrm{M}+\mathrm{H}- \\
\left.\mathrm{C}_{10} \mathrm{H}_{12} \mathrm{O}_{2}\right]^{+} \\
177.0754[\mathrm{M}+\mathrm{H}- \\
\left.\mathrm{C}_{10} \mathrm{H}_{12} \mathrm{O}_{2}-\mathrm{CH}_{3}\right]^{+} \\
149.1734[\mathrm{M}+\mathrm{H}- \\
\left.\mathrm{C}_{10} \mathrm{H}_{12} \mathrm{O}_{2}-\mathrm{CH}_{3}-\mathrm{CO}\right]^{+}\end{array}$ \\
\hline
\end{tabular}


165.0915[M+H-

$\left.\mathrm{C}_{11} \mathrm{H}_{13} \mathrm{NO}_{2}\right]+$,

\begin{tabular}{|c|c|c|c|c|c|c|c|}
\hline 43 & 4.26 & (-)-Corlumine & $\mathrm{C}_{21} \mathrm{H}_{21} \mathrm{NO}_{6}$ & 383.1396 & 384.1447 & 0 & $\begin{array}{l}368.1106\left[\mathrm{M}+\mathrm{H}-\mathrm{H}_{2} \mathrm{O}\right]^{+} \\
249.0520\end{array}$ \\
\hline
\end{tabular}

$44 \quad 4.29 \quad$ Chebulinic Acid* $\quad \mathrm{C}_{41} \mathrm{H}_{32} \mathrm{O}_{27} \quad 956.1631 \quad 955.1034 \quad 0.2 \quad 803.2881[\mathrm{M}-\mathrm{H}-\mathrm{galloyl]}$;

651.3185[M-H-

2galloyl]', 633.1791[M-

H-2galloyl-gallic]',

499.4882[M-H-

3galloyl]

\begin{tabular}{|c|c|c|c|c|c|c|c|}
\hline 45 & 4.37 & $\begin{array}{l}\text { 3-galloyl-2,4-chebuloyl- } \\
\text { 1,6-HHDP-glucose }\end{array}$ & $\mathrm{C}_{41} \mathrm{H}_{30} \mathrm{O}_{27}$ & 954.0975 & 953.0885 & -0.2 & $\begin{array}{l}454.2341[\mathrm{M}-\mathrm{H}- \\
\mathrm{COOH}]^{2-} \\
300.9994[\mathrm{Hexahydroxy} \\
\text { diphenoyl-H]', }\end{array}$ \\
\hline
\end{tabular}

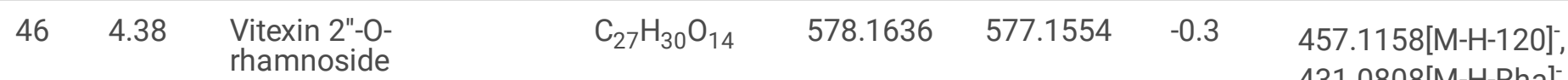

431.0808[M-H-Rha]',

413.0879[M-H-Rha-

$\left.\mathrm{H}_{2} \mathrm{O}\right]^{-}, 341.3668[\mathrm{M}-\mathrm{H}-$

Rha-90], 311.0567[M-

H-Rha-120]',

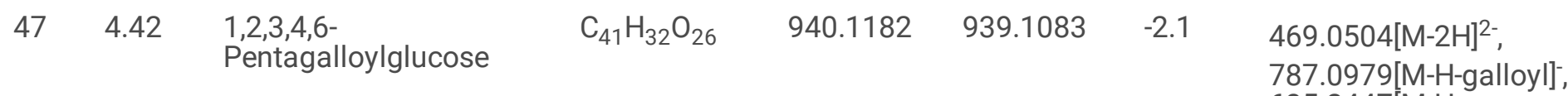
635.2447[M-H-

2galloyl]', 483.3546[M-

H-3galloyl];

331.4498[M-H-

4galloyl]

$\begin{array}{lllll}48.49(+) \text {-Bicuculline* } \quad \mathrm{C}_{20} \mathrm{H}_{17} \mathrm{NO}_{6} \quad 367.1056 \quad 368.1145 \quad 1.1 \quad & 307.0586[\mathrm{M}+\mathrm{H}- \\ & & & \left.\mathrm{NH}_{2} \mathrm{CH}_{3}-\mathrm{H}_{2} \mathrm{O}-\mathrm{CH}_{3}\right]^{+} \\ & & & 277.0499,249.0520 \\ & & & 190.0849\end{array}$

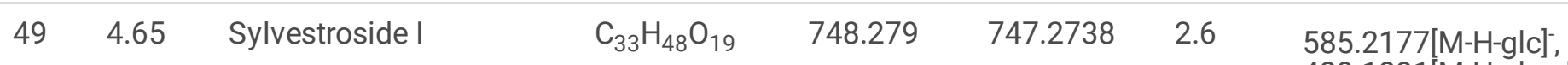
423.1231[M-H-glc-glc]-

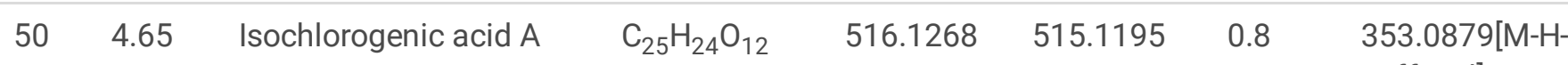

caffeoyl]', 191.0553[M-

H-2caffeoyl];

179.0343[M-H-

2caffeoyl- $\left.\mathrm{H}_{2} \mathrm{O}\right]^{-}$,

135.0446[caffeic acid$\left.\mathrm{H}-\mathrm{CO}_{2}\right]^{-}$

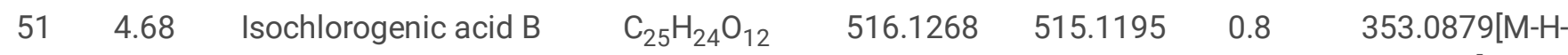

caffeoyl]', 191.0553[M-

H-2caffeoyl];

179.0343[M-H-

2caffeoyl- $\left.\mathrm{H}_{2} \mathrm{O}\right]^{-}$,

135.0446[caffeic acid$\left.\mathrm{H}-\mathrm{CO}_{2}\right]^{-}$

$\begin{array}{llllllll}52 & 4.86 & (-) \text {-Bicuculline } & \mathrm{C}_{20} \mathrm{H}_{17} \mathrm{NO}_{6} & 367.1056 & 368.1145 & 1.1 & 307.0586[\mathrm{M}+\mathrm{H}-\end{array}$ 


\begin{tabular}{|c|c|c|c|c|c|c|c|}
\hline & & & & & & & $\begin{array}{l}\left.\mathrm{NH}_{2} \mathrm{CH}_{3}-\mathrm{H}_{2} \mathrm{O}-\mathrm{CH}_{3}\right]^{+} \\
\text {277.0499, } \\
190.0849 .0520\end{array}$ \\
\hline 53 & 5.01 & Cassiaside B2 & $\mathrm{C}_{39} \mathrm{H}_{52} \mathrm{O}_{25}$ & 920.2798 & 919.2737 & -1.7 & $\begin{array}{l}271.0601[\mathrm{M}-\mathrm{H}-4 \mathrm{glc}]^{-} \\
257.0369\left[\mathrm{M}-\mathrm{H}-4 \mathrm{glc}^{-}\right. \\
\left.\mathrm{CH}_{3}\right]^{-}\end{array}$ \\
\hline 54 & 5.09 & Protopine & $\mathrm{C}_{20} \mathrm{H}_{19} \mathrm{NO}_{5}$ & 353.1263 & 354.1339 & -0.3 & $\begin{array}{l}336.1216\left[\mathrm{M}+\mathrm{H}-\mathrm{H}_{2} \mathrm{O}\right]^{+} \\
188.0672[\mathrm{M}+\mathrm{H}- \\
\left.\mathrm{C}_{9} \mathrm{H}_{8} \mathrm{O}_{2}-\mathrm{H}_{2} \mathrm{O}\right]^{+} \\
149,0582[\mathrm{M}+\mathrm{H}- \\
\left.\mathrm{C}_{11} \mathrm{H}_{11} \mathrm{NO}_{3}\right]^{+}\end{array}$ \\
\hline 55 & 5.15 & Cantleyoside & $\mathrm{C}_{33} \mathrm{H}_{46} \mathrm{O}_{19}$ & 746.2633 & 745.2544 & -1.5 & $\begin{array}{l}\text { 583.2032[M-H-glc }]^{-} \\
421.1159[\mathrm{M}-\mathrm{H}-2 \mathrm{glc}]^{-}\end{array}$ \\
\hline 56 & 5.21 & Crocin I* & $\mathrm{C}_{44} \mathrm{H}_{64} \mathrm{O}_{24}$ & 976.3787 & 975.3721 & 1.3 & $\begin{array}{l}\text { 813.3179[M-H-glc] } \\
\text { 651.2274[M-H-2glc] }\end{array}$ \\
\hline 57 & 5.26 & Medicarpin & $\mathrm{C}_{16} \mathrm{H}_{14} \mathrm{O}_{4}$ & 270.0892 & 269.0831 & -0.2 & $\begin{array}{l}159.0242[\mathrm{M}-\mathrm{H}- \\
\left.\mathrm{C}_{6} \mathrm{H}_{6} \mathrm{O}_{2}\right]^{-}\end{array}$ \\
\hline 58 & 5.28 & Cassiaside & $\mathrm{C}_{20} \mathrm{H}_{20} \mathrm{O}_{10}$ & 404.4257 & 403.1398 & -0.4 & $257.0454[\mathrm{M}-\mathrm{H}-\mathrm{glc}]^{-}$ \\
\hline 59 & 5.36 & $\begin{array}{l}\text { Aurantio-obtusin-6-O- } \beta \text { - } \\
\text { D-glucoside }\end{array}$ & $\mathrm{C}_{23} \mathrm{H}_{24} \mathrm{O}_{12}$ & 492.1268 & 491.1199 & -1.4 & $\begin{array}{l}476.0960\left[\mathrm{M}-\mathrm{H}-\mathrm{CH}_{3}\right]^{-}, \\
461.0760\left[\mathrm{M}-\mathrm{H}-2 \mathrm{CH}_{3}\right]^{-}, \\
329.0694[\mathrm{M}-\mathrm{H}-\mathrm{glc}]^{-}, \\
314.0418[\mathrm{M}-\mathrm{H}-\mathrm{glc}- \\
\left.\mathrm{CH}_{3}\right]^{-}, 286.0182[\mathrm{M}-\mathrm{H}- \\
\left.\text { glc-CH}_{3}-\mathrm{CO}\right]^{-}, \\
258.0227[\mathrm{M}-\mathrm{H}-\mathrm{glc}-\mathrm{CH} 3- \\
2 \mathrm{CO}^{-}\end{array}$ \\
\hline 60 & 5.37 & (-)-Chelidonine & $\mathrm{C}_{20} \mathrm{H}_{19} \mathrm{NO}_{5}$ & 353.1263 & 354.1339 & -0.3 & $\begin{array}{l}336.1216\left[\mathrm{M}+\mathrm{H}-\mathrm{H}_{2} \mathrm{O}\right]^{+} \\
322.1068[\mathrm{M}+\mathrm{H}- \\
\left.\mathrm{NH}_{2} \mathrm{CH}_{3}\right]^{+}\end{array}$ \\
\hline 61 & 5.39 & Coptisine & $\mathrm{C}_{19} \mathrm{H}_{14} \mathrm{NO}_{4}+$ & 320.0923 & 320.0899 & 2.4 & $\begin{array}{l}292.0939[\mathrm{M}-\mathrm{CO}]^{+} \\
262.0863\left[\mathrm{M}-\mathrm{CH}_{2} \mathrm{O}\right]^{+}\end{array}$ \\
\hline 62 & 5.46 & Diosbulbin J-glucoside & $\mathrm{C}_{26} \mathrm{H}_{36} \mathrm{O}_{12}$ & 540.1843 & 539.1772 & -0.5 & $\begin{array}{l}\text { 377.1246[M-H-glc]', } \\
\text { 349.0827[M-H-glc-CO] }\end{array}$ \\
\hline 63 & 5.51 & Jatrorrhizine & $\mathrm{C}_{20} \mathrm{H}_{20} \mathrm{NO}_{4}+$ & 338.1392 & 338.1395 & 0.5 & $\begin{array}{l}323.1228\left[\mathrm{M}-\mathrm{CH}_{3}\right]^{+}, \\
308.0904\left[\mathrm{M}-2 \mathrm{CH}_{3}\right]^{+}, \\
280.0947\left[\mathrm{M}-2 \mathrm{CH}_{3}^{-}\right. \\
\mathrm{CO}]^{+}\end{array}$ \\
\hline 64 & 5.63 & Crocin II & $\mathrm{C}_{38} \mathrm{H}_{54} \mathrm{O}_{19}$ & 814.3259 & 813.3167 & -1.4 & $\begin{array}{l}\text { 651.2267[M-H-glc }]^{-} \\
\text {489.2274[M-H-2glc] }\end{array}$ \\
\hline 65 & 5.77 & Apigenin & $\mathrm{C}_{15} \mathrm{H}_{10} \mathrm{O}_{5}$ & 270.0892 & 269.0831 & -0.4 & $\begin{array}{l}251.0343\left[\mathrm{M}-\mathrm{H}-\mathrm{H}_{2} \mathrm{O}\right]^{-} \\
241.4335[\mathrm{M}-\mathrm{H}-\mathrm{CO}]^{-}\end{array}$ \\
\hline
\end{tabular}




\begin{tabular}{|c|c|c|c|c|c|c|c|}
\hline 66 & 6.04 & Quercetin* & $\mathrm{C}_{15} \mathrm{H}_{10} \mathrm{O}_{7}$ & 302.0427 & 301.0364 & -0.4 & $\begin{array}{l}283.1690\left[\mathrm{M}-\mathrm{H}-\mathrm{H}_{2} \mathrm{O}\right]^{-}, \\
273.0665[\mathrm{M}-\mathrm{H}-\mathrm{glc}-\mathrm{CO}]^{-}, \\
163.0189\left[\mathrm{~A}^{0,2}\right]^{-}, \\
151.0033\left[\mathrm{~A}^{1,3}\right]^{-}\end{array}$ \\
\hline 67 & 6.17 & Diosbulbin L-glucoside & $\mathrm{C}_{25} \mathrm{H}_{32} \mathrm{O}_{12}$ & 524.1894 & 523.1837 & 2.1 & $\begin{array}{l}\text { 361.2174[M-H-glc]', } \\
\text { 333.0882[M-H-glc-CO] }\end{array}$ \\
\hline 68 & 6.34 & Obtusin & $\mathrm{C}_{18} \mathrm{H}_{16} \mathrm{O}_{7}$ & 344.0896 & 343.0824 & -0.7 & $\begin{array}{l}328.0227[\mathrm{M}-\mathrm{H}- \\
\left.\mathrm{CH}_{3}\right]^{-}, 313.0284[\mathrm{M}-\mathrm{H}- \\
\left.2 \mathrm{CH}_{3}\right]^{-}, 285.0477[\mathrm{M}- \\
\left.\mathrm{H}_{2} \mathrm{CH}_{3}-\mathrm{CO}\right]^{-} \\
270.9883\left[\mathrm{M}-\mathrm{H}-3 \mathrm{CH}_{3}-\right. \\
\mathrm{CO}_{-}, 242.9933[\mathrm{M}-\mathrm{H}- \\
\left.3 \mathrm{CH}_{3}-2 \mathrm{CO}\right]\end{array}$ \\
\hline 69 & 6.37 & Dihydrochelerythrine & $\mathrm{C}_{21} \mathrm{H}_{19} \mathrm{NO}_{4}$ & 349.1314 & 350.136 & -3.2 & 334.1060[M+H-CH$]^{+}$ \\
\hline 70 & 6.87 & Dehydrocorydaline & $\mathrm{C}_{22} \mathrm{H}_{24} \mathrm{NO}_{4}+$ & 366.1705 & 366.1695 & -1 & $\begin{array}{l}366.1695[\mathrm{M}]^{+}, \\
351.1484\left[\mathrm{M}-\mathrm{CH}_{3}\right]^{+}, \\
334.1060\left[\mathrm{M}-2 \mathrm{CH}_{3}\right]^{+},\end{array}$ \\
\hline 71 & 7.10 & Kaempferol & $\mathrm{C}_{15} \mathrm{H}_{10} \mathrm{O}_{6}$ & 286.0477 & 285.0397 & -0.2 & $\begin{array}{l}\text { 257.0296[M-H-CO }]^{-}, \\
243.0245\left[\mathrm{M}-\mathrm{H}-\mathrm{C}_{2} \mathrm{H}_{2} \mathrm{O}\right]^{-}, \\
227.0345[\mathrm{M}-\mathrm{H}-\mathrm{CO}- \\
\mathrm{CHOH}]^{-}, 151.0076\left[\mathrm{~A}^{1,3}-\right. \\
\mathrm{H}^{-}, 133.0318\left[\mathrm{~B}^{1,3}\right]^{-}\end{array}$ \\
\hline 72 & 7.46 & Formononetin & $\mathrm{C}_{16} \mathrm{H}_{12} \mathrm{O}_{4}$ & 268.2604 & 267.0657 & 0 & $252.0417\left[\mathrm{M}-\mathrm{H}-\mathrm{CH}_{3}\right]^{-}$ \\
\hline 73 & 7.68 & $\begin{array}{l}\text { Crocin I / Cis-trans } \\
\text { isomer }\end{array}$ & $\mathrm{C}_{44} \mathrm{H}_{64} \mathrm{O}_{24}$ & 976.3787 & 975.3695 & 1.3 & $\begin{array}{l}\text { 813.3179[M-H-glc }]^{-} \\
651.2274[\mathrm{M}-\mathrm{H}-2 \mathrm{glc}]^{-}\end{array}$ \\
\hline 74 & 7.99 & $\begin{array}{l}\text { Cis- Crocin II / Cis-trans } \\
\text { isomer }\end{array}$ & $\mathrm{C}_{38} \mathrm{H}_{54} \mathrm{O}_{19}$ & 814.3259 & 813.3153 & -1.4 & $\begin{array}{l}\text { 651.2267[M-H-glc] } \\
\text { 489.2274[M-H-2glc] }\end{array}$ \\
\hline 75 & 8.13 & Aurantio-obtusin & $\mathrm{C}_{17} \mathrm{H}_{14} \mathrm{O}_{7}$ & 330.0739 & 329.0667 & -1.4 & $\begin{array}{l}314.0415\left[\mathrm{M}-\mathrm{H}-\mathrm{CH}_{3}\right]^{-} \\
299.0197[\mathrm{M}-\mathrm{H}- \\
\left.2 \mathrm{CH}_{3}\right]^{-}, 285.0402[\mathrm{M}-\mathrm{H}- \\
\left.\mathrm{CO}_{2}\right]^{-}, 271.0520[\mathrm{M}-\mathrm{H}- \\
\left.2 \mathrm{CH}_{3}-\mathrm{CO}\right]^{-}\end{array}$ \\
\hline 76 & 8.25 & $\begin{array}{l}\text { Trihydroxy-a-boswellic } \\
\text { acid }\end{array}$ & $\mathrm{C}_{30} \mathrm{H}_{48} \mathrm{O}_{6}$ & 504.3451 & 503.3388 & 1.6 & - \\
\hline 77 & 8.30 & $\begin{array}{l}\text { Trihydroxy- } \beta \text {-Boswellic } \\
\text { acid }\end{array}$ & $\mathrm{C}_{30} \mathrm{H}_{48} \mathrm{O}_{6}$ & 504.3451 & 503.3388 & 1.6 & - \\
\hline 78 & 8.43 & $\begin{array}{l}\text { Dihydroxy-11-Keto- } \beta- \\
\text { boswellic acid }\end{array}$ & $\mathrm{C}_{30} \mathrm{H}_{46} \mathrm{O}_{6}$ & 502.3294 & 501.3236 & 2 & - \\
\hline 79 & 8.55 & Isorhamnetin & $\mathrm{C}_{16} \mathrm{H}_{12} \mathrm{O}_{7}$ & 316.0583 & 315.0514 & 1.3 & $\begin{array}{l}300.0275\left[\mathrm{M}-\mathrm{H}-\mathrm{CH}_{3}\right]^{-} \\
272.0320\left[\mathrm{M}-\mathrm{H}-\mathrm{CH}_{3}-\right. \\
\mathrm{CO}]^{-}, 151.0469\left[\mathrm{~A}^{1,3}\right]^{-} \\
163.0424\left[\mathrm{~B}^{1,3}\right]^{-}\end{array}$ \\
\hline
\end{tabular}




\begin{tabular}{|c|c|c|c|c|c|c|c|}
\hline 80 & 8.60 & $\begin{array}{l}\text { Taurochenodeoxycholic } \\
\text { acid (TDCA) }\end{array}$ & $\mathrm{C}_{26} \mathrm{H}_{45} \mathrm{NO}_{6} \mathrm{~S}$ & 499.2968 & 498.2893 & -1.1 & $\begin{array}{l}\left.\text { 480.3216[M-H-H } \mathrm{H}_{2} \mathrm{O}\right]^{-} \\
\text {427.3157[M-H-HSO}]_{3}^{-} \\
373.2737\left[\mathrm{M}-\mathrm{H}-\mathrm{HSO}_{3}-\right. \\
\left.\mathrm{C}_{2} \mathrm{H}_{5} \mathrm{~N}\right]^{-}\end{array}$ \\
\hline 81 & 9.21 & Cholic Acid (CA) & $\mathrm{C}_{24} \mathrm{H}_{40} \mathrm{O}_{5}$ & 408.2876 & 407.2807 & -1.6 & $\begin{array}{l}\left.\text { 389.2747[M-H-H }{ }_{2} \mathrm{O}\right]^{-} \\
\text {362.2839[M-H-COOH]', } \\
\text { 343.2640[M-H-COOH-' } \\
\left.\mathrm{H}_{2} \mathrm{O}\right]^{-}\end{array}$ \\
\hline 82 & 9.28 & Kaempferide & $\mathrm{C}_{16} \mathrm{H}_{12} \mathrm{O}_{6}$ & 300.0634 & 299.0562 & 0.3 & $\begin{array}{l}\text { 284.0323[M-H-CH}]^{-} \\
\text {271.0606[M-H-CO]', } \\
\left.\text { 151.0076[A } \mathrm{A}^{1,3}-\mathrm{H}\right]^{-}\end{array}$ \\
\hline 83 & 9.56 & $\begin{array}{l}\text { Ursodeoxycholic acid* } \\
\text { (UDCA) }\end{array}$ & $\mathrm{C}_{24} \mathrm{H}_{40} \mathrm{O}_{4}$ & 392.2927 & 391.2856 & 0.3 & $\begin{array}{l}\left.\text { 373.2657[M-H-H } \mathrm{H}_{2} \mathrm{O}\right]^{-} \\
\text {346.0562[M-H-COOH]', } \\
\text { 328.0393[M-H-COOH- } \\
\left.\mathrm{H}_{2} \mathrm{O}\right]^{-}\end{array}$ \\
\hline 84 & 9.77 & $\begin{array}{l}\text { Dihydroxy-a-boswellic } \\
\text { acid }\end{array}$ & $\mathrm{C}_{30} \mathrm{H}_{48} \mathrm{O}_{5}$ & 488.3502 & 487.3443 & 1.7 & - \\
\hline 85 & 10.05 & $\begin{array}{l}\text { Dihydroxy- } \beta \text {-boswellic } \\
\text { acid }\end{array}$ & $\mathrm{C}_{30} \mathrm{H}_{48} \mathrm{O}_{5}$ & 488.3502 & 487.3443 & 1.7 & - \\
\hline 86 & 10.20 & Galangin & $\mathrm{C}_{15} \mathrm{H}_{10} \mathrm{O}_{5}$ & 270.0528 & 269.0454 & 0.3 & $\begin{array}{l}\left.\text { 251.1652[M-H-H }{ }_{2} \mathrm{O}\right] \\
225.0555\left[\mathrm{M}-\mathrm{H}-\mathrm{CO}_{2}\right]- \\
151.1026\left[\mathrm{~A}^{1,3}\right]-\end{array}$ \\
\hline 87 & 10.33 & Rhamnazin & $\mathrm{C}_{17} \mathrm{H}_{14} \mathrm{O}_{7}$ & 330.074 & 329.0668 & 0.5 & $\begin{array}{l}314.0431\left[\mathrm{M}-\mathrm{H}-\mathrm{CH}_{3}\right]^{-} \\
299.0197\left[\mathrm{M}-\mathrm{H}-\mathrm{CH}_{3}-\right. \\
\left.\mathrm{CH}_{3}\right]^{-}, 271.02487[\mathrm{M}-\mathrm{H}- \\
\left.2 \mathrm{CH}_{3}-\mathrm{CO}\right]^{-} \\
165.1026\left[\mathrm{~A}^{1,3}\right]^{-}\end{array}$ \\
\hline 88 & 11.35 & $\begin{array}{l}\text { 11-hydroxy-a-boswellic } \\
\text { acid }\end{array}$ & $\mathrm{C}_{30} \mathrm{H}_{48} \mathrm{O}_{4}$ & 472.3553 & 471.3478 & 2 & $\begin{array}{l}409.2831\left[\mathrm{M}-\mathrm{H}-\mathrm{H}_{2} \mathrm{O}-\right. \\
\left.\mathrm{CO}_{2}\right]^{-}, 239.2327\left[\mathrm{~B}^{8,9}\right]^{-} \\
233.2012\left[\mathrm{D}^{8,9}\right]^{-}\end{array}$ \\
\hline 89 & 11.38 & $\begin{array}{l}\text { 11-hydroxy- } \beta \text {-boswellic } \\
\text { acid }\end{array}$ & $\mathrm{C}_{30} \mathrm{H}_{48} \mathrm{O}_{4}$ & 472.3553 & 471.3476 & 2 & $\begin{array}{l}409.2831\left[\mathrm{M}-\mathrm{H}-\mathrm{H}_{2} \mathrm{O}-\right. \\
\left.\mathrm{CO}_{2}\right]^{-}, 239.2327\left[\mathrm{~B}^{8,9}\right]^{-} \\
233.2012\left[\mathrm{D}^{8,9}\right]^{-}\end{array}$ \\
\hline 90 & 11.48 & $\begin{array}{l}\text { 2a-hydroxy-oleanolic } \\
\text { acid }\end{array}$ & $\mathrm{C}_{30} \mathrm{H}_{48} \mathrm{O}_{4}$ & 472.3553 & 471.3478 & 2 & $\begin{array}{l}\left.\text { 453.3402 [M-H- } \mathrm{H}_{2} \mathrm{O}\right]^{-} \\
\text {407.3328 [M-H- } \mathrm{H}_{2} \mathrm{O}- \\
\left.\mathrm{CO}_{2}\right]^{-}\end{array}$ \\
\hline 91 & 12.78 & Oleanolic acid* & $\mathrm{C}_{30} \mathrm{H}_{48} \mathrm{O}_{3}$ & 456.3604 & 455.3528 & -1.8 & $\begin{array}{l}393.3420\left[\mathrm{M}-\mathrm{H}-\mathrm{H}_{2} \mathrm{O}-\right. \\
\left.\mathrm{CO}_{2}\right]^{-}, 239.1201\left[\mathrm{~B}^{8,9}\right]^{-} \\
217.2012\left[\mathrm{D}^{8,9}\right]^{-}\end{array}$ \\
\hline 92 & 12.87 & a-boswellic acid & $\mathrm{C}_{30} \mathrm{H}_{48} \mathrm{O}_{3}$ & 456.3604 & 455.3532 & -1.8 & $393.3420\left[\mathrm{M}-\mathrm{H}-\mathrm{H}_{2} \mathrm{O}-\right.$ \\
\hline
\end{tabular}




\begin{tabular}{|c|c|c|c|c|c|c|c|}
\hline & & & & & & & $\begin{array}{l}\left.\mathrm{CO}_{2}\right]^{-}, 239.1201\left[\mathrm{~B}^{8,9}\right]^{-} \\
217.2012\left[\mathrm{D}^{8,9}\right]^{-}\end{array}$ \\
\hline 93 & 13.21 & Myristic acid & $\mathrm{C}_{14} \mathrm{H}_{28} \mathrm{O}_{2}$ & & 227.2017 & 0.1 & - \\
\hline 94 & 12.89 & $\begin{array}{l}\text { Acetyl-11-keto- } \beta- \\
\text { boswellic acid }\end{array}$ & $\mathrm{C}_{32} \mathrm{H}_{48} \mathrm{O}_{5}$ & 512.3502 & 511.3469 & 0.5 & $\begin{array}{l}469.8469\left[\mathrm{M}-\mathrm{H}-\mathrm{C}_{2} \mathrm{H}_{2} \mathrm{O}\right]^{-} \\
407.3417\left[\mathrm{M}-\mathrm{H}-\mathrm{C}_{2} \mathrm{H}_{2} \mathrm{O}-\right. \\
\left.\mathrm{H}_{2} \mathrm{O}-\mathrm{CO}_{2}\right]^{-} \\
280.1628\left[\mathrm{~B}^{8,9}\right]^{-} \\
231.8353\left[\mathrm{D}^{8,9}\right]^{-}\end{array}$ \\
\hline 95 & 13.82 & $\begin{array}{l}\text { 3-Acetyl- } \beta \text {-boswellic } \\
\text { acid }\end{array}$ & $\mathrm{C}_{32} \mathrm{H}_{50} \mathrm{O}_{4}$ & 498.3709 & 497.3632 & 1.6 & $\begin{array}{l}455.2737\left[\mathrm{M}-\mathrm{H}-\mathrm{C}_{2} \mathrm{H}_{2} \mathrm{O}\right]^{-} \\
393.8599\left[\mathrm{M}-\mathrm{H}-\mathrm{C}_{2} \mathrm{H}_{2} \mathrm{O}-\right. \\
\left.\mathrm{H}_{2} \mathrm{O}-\mathrm{CO}_{2}\right]^{-} \\
280.8910\left[\mathrm{~B}^{8,9}\right]^{-}, \\
217.8976\left[\mathrm{D}^{8,9}\right]^{-}\end{array}$ \\
\hline 96 & 14.70 & $\beta$-boswellic acid* & $\mathrm{C}_{30} \mathrm{H}_{48} \mathrm{O}_{3}$ & 456.3604 & 455.3532 & -1.8 & $\begin{array}{l}393.3420\left[\mathrm{M}-\mathrm{H}-\mathrm{H}_{2} \mathrm{O}-\right. \\
\left.\mathrm{CO}_{2}\right]^{-}, 239.1201\left[\mathrm{~B}^{8,9}\right]^{-} \\
217.2012\left[\mathrm{D}^{8,9}\right]^{-}\end{array}$ \\
\hline
\end{tabular}

* Components identified with standard substance.

Table 2. Potential bioactive compounds ADME values of ELP. 


\begin{tabular}{|llllll|}
\hline Number & Molecule ID & PubChem CID & Molecular name & OB (\%) & DL \\
\hline N1 & MOL006826 & 71308174 & chebulic acid & 72.00 & 0.32 \\
\hline N2 & MOL009038 & 3082301 & Genipin 1-gentiobioside & 45.58 & 0.83 \\
\hline N3 & MOL001002 & 5281855 & Ellagic acid & 43.06 & 0.43 \\
\hline N4 & MOL002322 & 162350 & Isovitexin & 31.29 & 0.72 \\
\hline N5 & MOL000098 & 5280343 & Quercetin & 46.43 & 0.28 \\
\hline N6 & MOL006475 & 155380 & Obtusin & 81.43 & 0.4 \\
\hline N7 & MOL000422 & 5280863 & Kaempferol & 41.88 & 0.24 \\
\hline N8 & MOL000392 & 5280378 & Formononetin & 69.67 & 0.21 \\
\hline N9 & MOL006472 & 155011 & Aurantio-obtusin & 31.55 & 0.37 \\
\hline N10 & MOL000354 & 5281654 & Isorhamnetin & 49.6 & 0.31 \\
\hline N11 & MOL004564 & 5281666 & Kaempferide & 73.41 & 0.27 \\
\hline N12 & MOL002563 & 5281616 & Galangin & 45.55 & 0.21 \\
\hline N13 & MOL008647 & 5280537 & Moupinamide & 86.71 & 0.26 \\
\hline N14 & MOL001467 & 10143 & Luteanin & 55.63 & 0.55 \\
\hline N15 & MOL000217 & 439654 & (S)-Scoulerine & 32.28 & 0.54 \\
\hline N16 & MOL004071 & 5417 & Tetrahydropalmatine & 73.94 & 0.64 \\
\hline N17 & MOL000791 & 185838 & (-)-Bicuculline & 69.67 & 0.88 \\
\hline N18 & MOL001481 & 978315 & (-)-Chelidonine & 48.32 & 0.86 \\
\hline N19 & MOL001458 & 72322 & Coptisine & 30.67 & 0.86 \\
\hline N20 & MOL006397 & 72323 & Jatrorrhizine & 30.44 & 0.75 \\
\hline N21 & MOL001461 & 485077 & Dihydrochelerythrine & 32.73 & 0.81 \\
\hline N22 & MOL004204 & 34781 & Dehydrocorydaline & 41.98 & 0.68 \\
\hline
\end{tabular}

\section{Supplemental Information}

\section{Supplementary Materials}

The following are available online. Figure S1: Chemical structures of the compounds identified from ELP. Figure S2: The fragmentation pathways of representative compounds from ELP. Table S1: The composition of ELP. Table S2: Targets of 22 potential bioactive compounds. Table S3: Target information of ELP in the treatment of RA. Table S4: Results of molecular docking simulation.

\section{Figures}


A

A
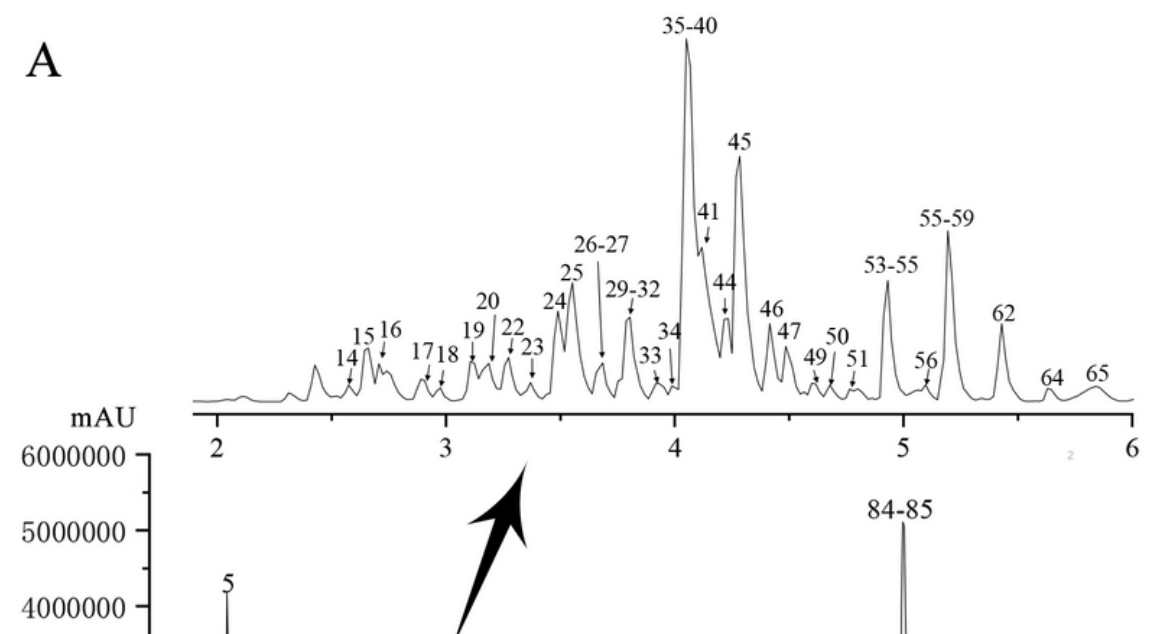

TOF MS ES-

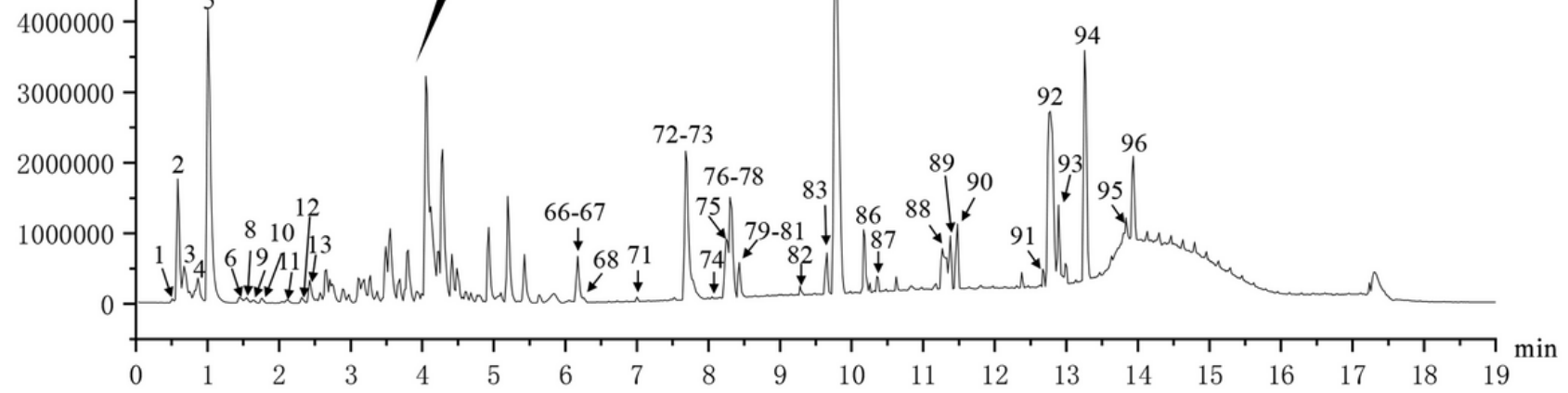

B

mAU

6000000

$5000000-$

$4000000-$

$3000000-$

$2000000-$

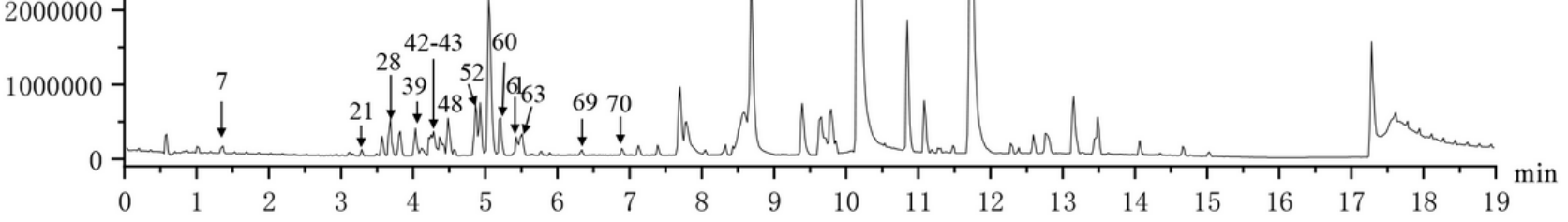

\section{Figure 1}

UPLC-Q-TOF-MS total ion chromatogram of ELP. (A) negative mode; (B) positive mode. 
<smiles>O=C(O)CC(C(=O)O)C1c2c(cc(O)c(O)c2O)C(=O)OC1C(=O)O</smiles>

Chebulic acid (N1)<smiles></smiles>

Quercetin (N5)<smiles>COc1c(O)cc2c(c1O)C(=O)c1c(cc(C)c(O)c1OC)C2=O</smiles>

Aurantio-obtusin (N9)<smiles>COc1cc(/C=C/C(=O)NCCc2ccc(O)cc2)ccc1O</smiles>

Moupinamide (N13)<smiles></smiles>

(-)-Bicuculline (N17)

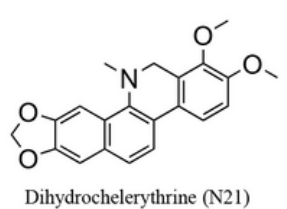

Dihydrochelerythrine (N21)<smiles>COC(=O)[C@@H]1CC[C@H](CO)[C@@H]1OC1OC(COC2OC(O)C(O)C(O)C2O)C(O)C(O)C1O</smiles>

Genipin 1-gentiobioside (N2)<smiles>COc1cc2c(c(O)c1OC)C(=O)c1c(cc(C)c(O)c1OC)C2=O</smiles>

Obtusin (N6)<smiles>COc1ccc(C2Oc3c(O)cc(O)cc3C(O)C2O)cc1O</smiles>

Isorhamnetin (N10)<smiles>CCN(C)C1Cc2cc(OC)c(OC)c(O)c2-c2c1ccc(OC)c2O</smiles>

Isocorydine (N14)<smiles>CN1Cc2c(ccc3c2OCO3)[C@@H]2[C@H](O)Cc3cc4c(cc3[C@@H]21)OCO4</smiles>

(-)-Chelidonine (N18)<smiles>COc1cc2c(cc1OC)-c1c(C)c3ccc(OC)c(OC)c3c[n+]1CC2</smiles>

Dehydrocorydaline (N22)

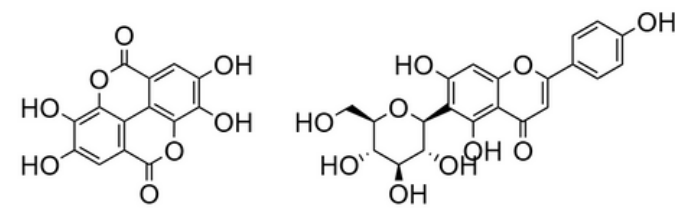

Ellagic acid (N3)<smiles></smiles>

Kaempferol (N7)<smiles>COc1ccc(C2Oc3c(O)cc(O)cc3OC2(O)O)cc1</smiles>

Kaempferide (N11)<smiles>COc1cc2c(cc1O)C1Cc3ccc(OC)c(O)c3CN1CC2</smiles>

Scoulerine (N15)<smiles></smiles>

Coptisine (N19)

Jatrorrhizine (N20)

Figure 2

Structures of 22 potential bioactive compounds of ELP. 


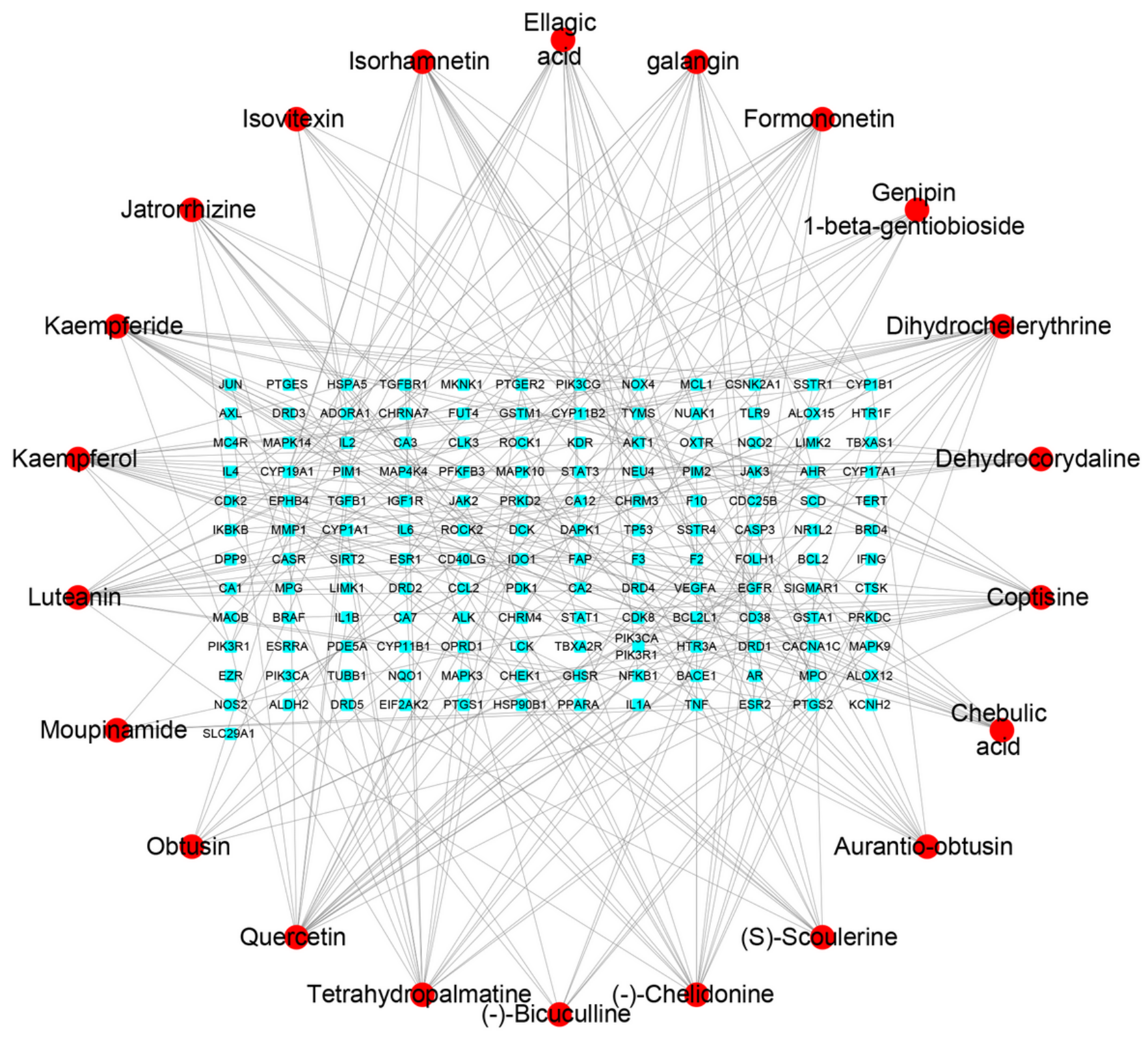

Potential bioactive compounds

Targets

\section{Figure 3}

Compound-target network of ELP. In the network, there are 167 nodes and 292 edges. 22 bioactive compounds have interactions with 145 protein targets. The red circles represent the bioactive compounds, and the blue squares represent the targets. 


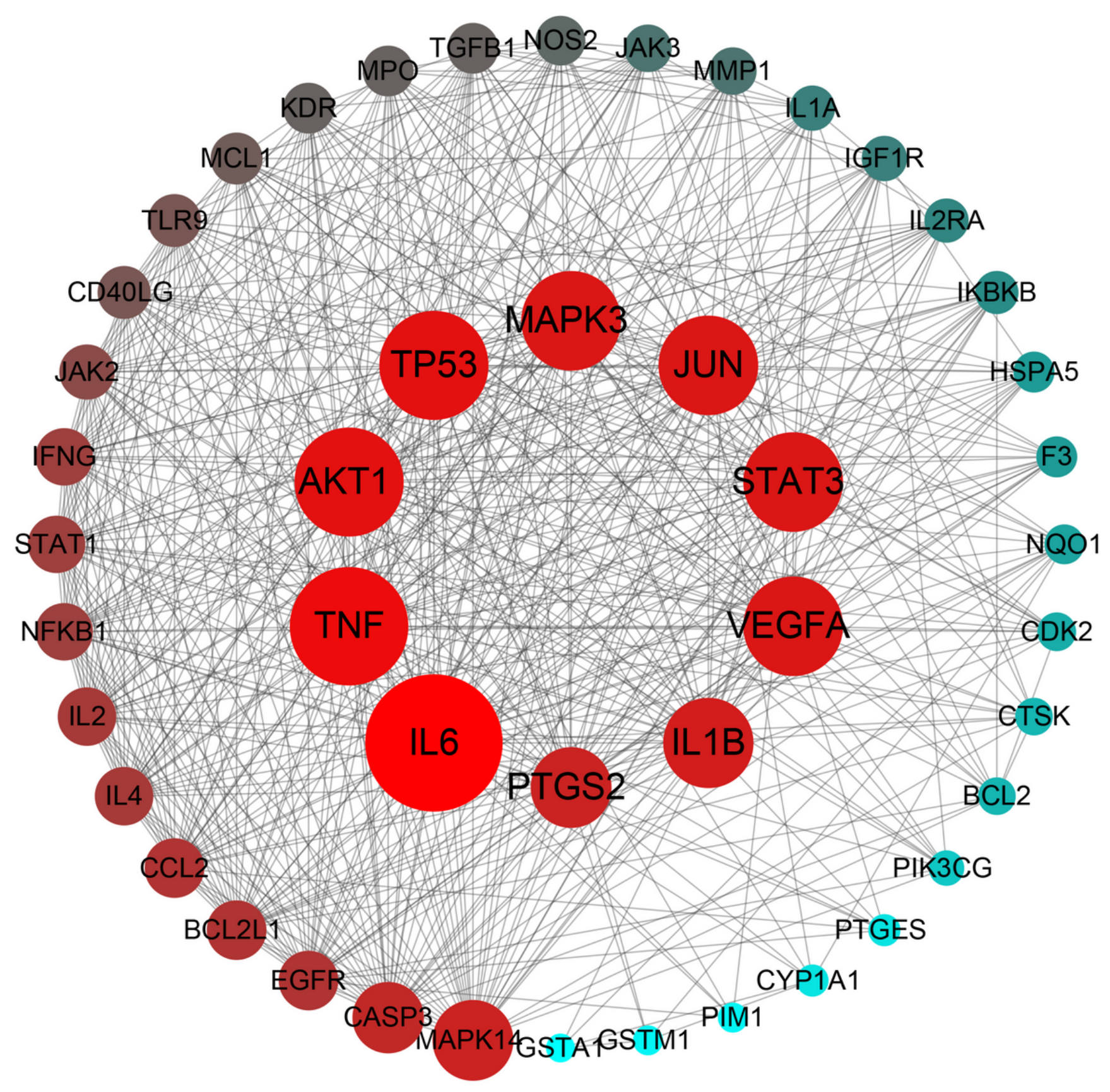

Figure 4

Protein-protein interaction (PPI) network of ELP for the treatment of rheumatoid arthritis. In the network, there are 46 nodes and 563 edges. Each node represents the relevant gene, the size and color of the node represent the value of the free degree. (the larger the node, the redder the color, the greater the free degree). 

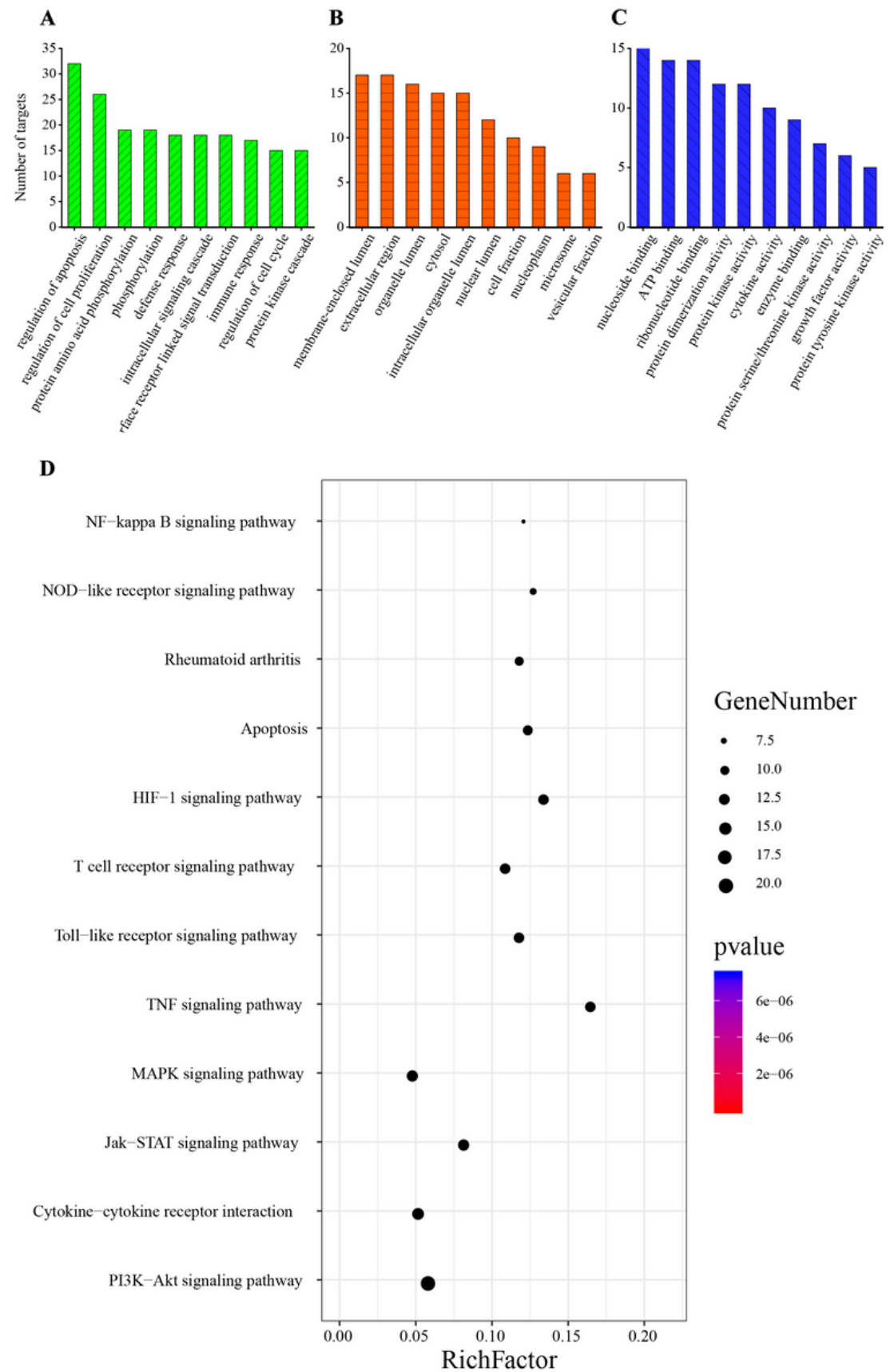

\section{Figure 5}

The results of Gene Ontology enrichment and KEGG pathway analysis by DAVID. A: biological process (BP), B: cell component (CC), C: molecular function (MF), D: KEGG pathway analysis. The $\mathrm{P}$ value of each biological process was less than 0.01 . 


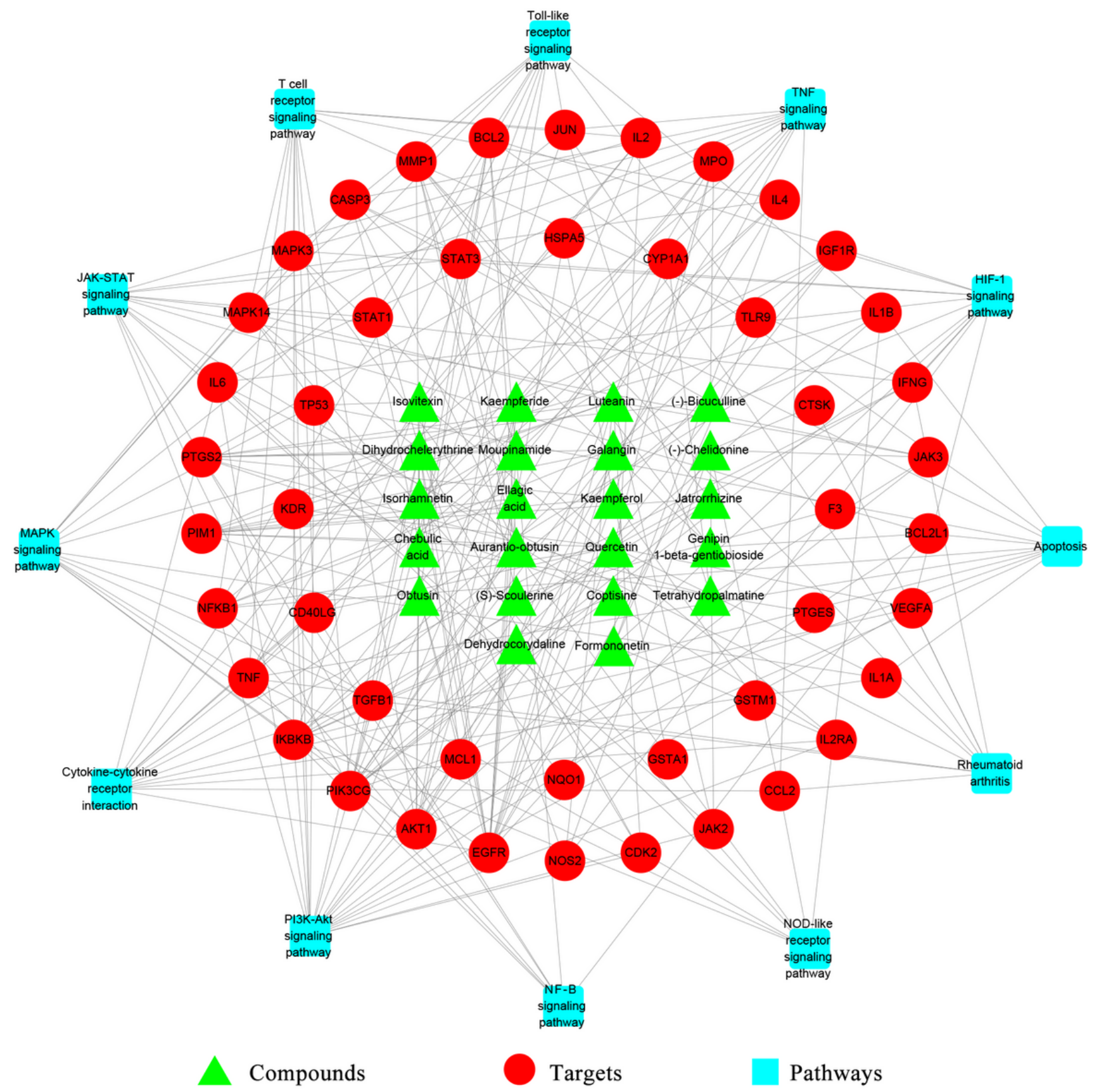

\section{Figure 6}

Compound-target-pathway Network (C-T-P) of ELP for treating RA. In the network, there are 80 nodes and 274 edges. The interaction relationship was shown between 22 bioactive compounds, 46 protein targets, and 12 signaling pathways. The green triangles represent the bioactive compounds, red circles represent targets, and blue squares represent signaling pathways. 


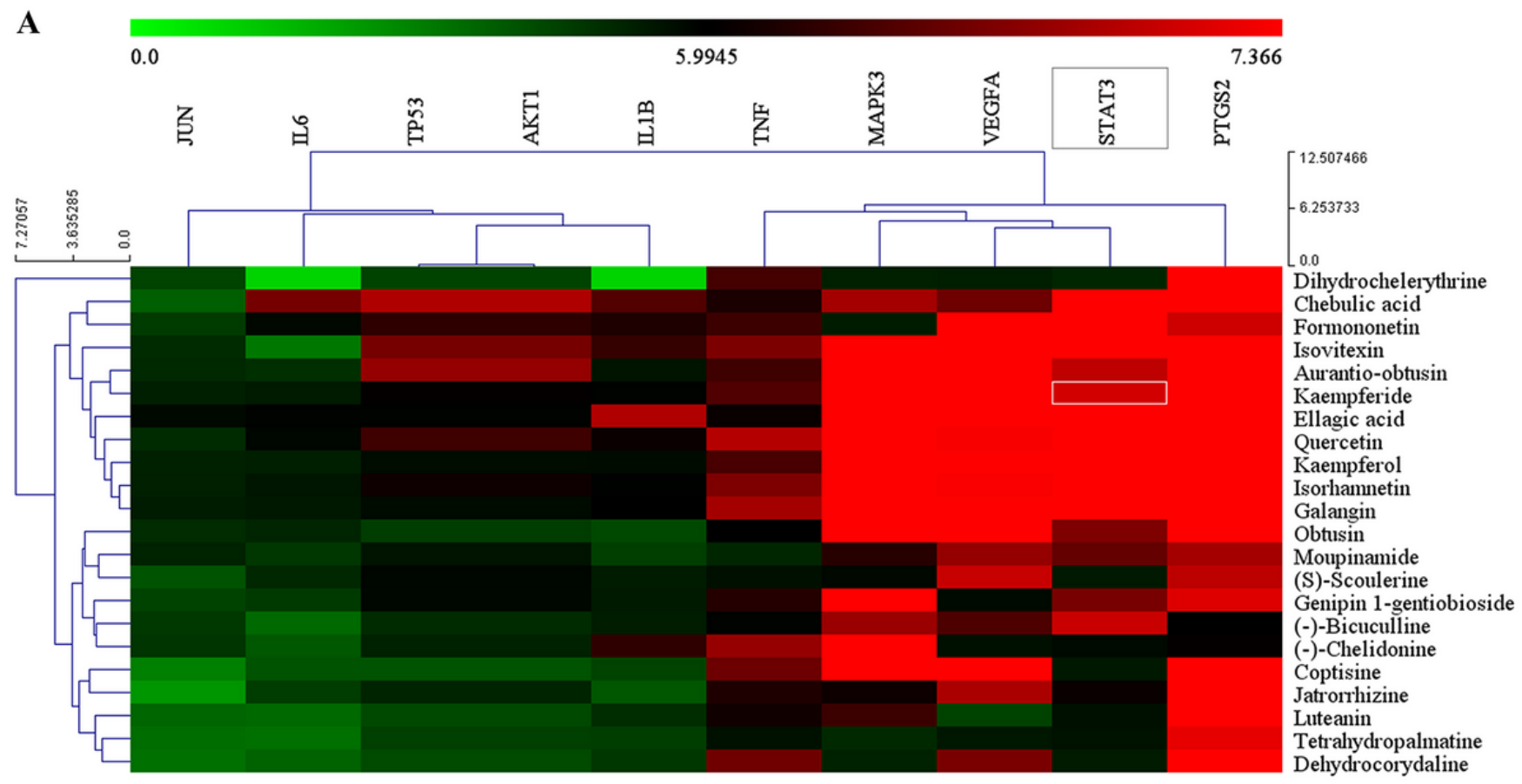

B
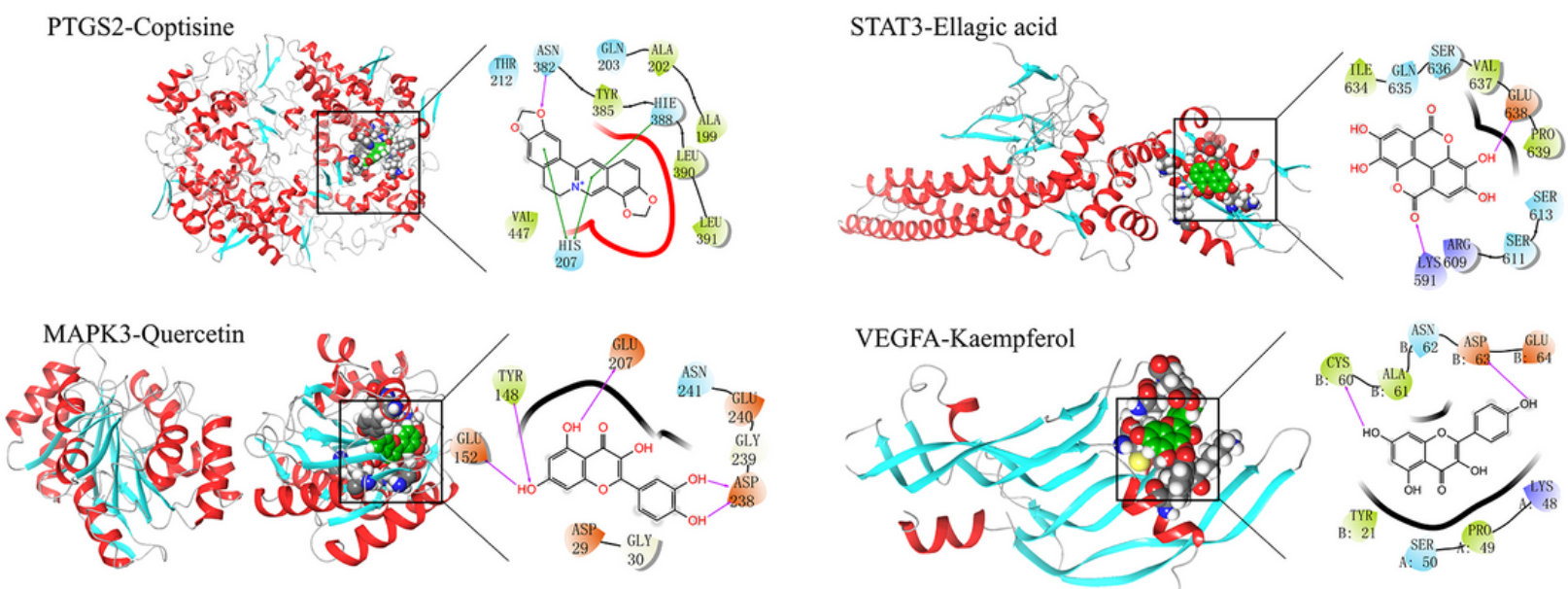

Interactions

$\longrightarrow$ Pi-Pi stacking $\longrightarrow$ H-Bond

Figure 7

Molecular docking results between 10 targets and 22 bioactive compounds from ELP. A: Heatmap for docking score. Docking score represents a negative logarithm of experimental dissociation/inhibition constant value (pKd/pKi). B: The typical Schematic representation of the molecular docking (Including 2D structure and 3D structure). Droplet shapes represent amino acid groups that interact with compounds in $3 \AA ̊$. Capital letters represent the abbreviation for amino acids. (Color Fig. can be accessed in the online version.)

\section{Supplementary Files}

This is a list of supplementary files associated with this preprint. Click to download.

- SupplementaryMaterials.docx

- Graphicalabstract.tif 